\title{
Business models in facilities management value chains
}

\author{
Jensen, Per Anker
}

Published in:

Journal of Corporate Real Estate

Link to article, DOI:

10.1108/jcre-07-2019-0034

Publication date:

2019

Document Version

Peer reviewed version

Link back to DTU Orbit

Citation (APA):

Jensen, P. A. (2019). Business models in facilities management value chains. Journal of Corporate Real Estate, 21(4), 307-323. https://doi.org/10.1108/jcre-07-2019-0034

\section{General rights}

Copyright and moral rights for the publications made accessible in the public portal are retained by the authors and/or other copyright owners and it is a condition of accessing publications that users recognise and abide by the legal requirements associated with these rights.

- Users may download and print one copy of any publication from the public portal for the purpose of private study or research.

- You may not further distribute the material or use it for any profit-making activity or commercial gain

- You may freely distribute the URL identifying the publication in the public portal

If you believe that this document breaches copyright please contact us providing details, and we will remove access to the work immediately and investigate your claim 


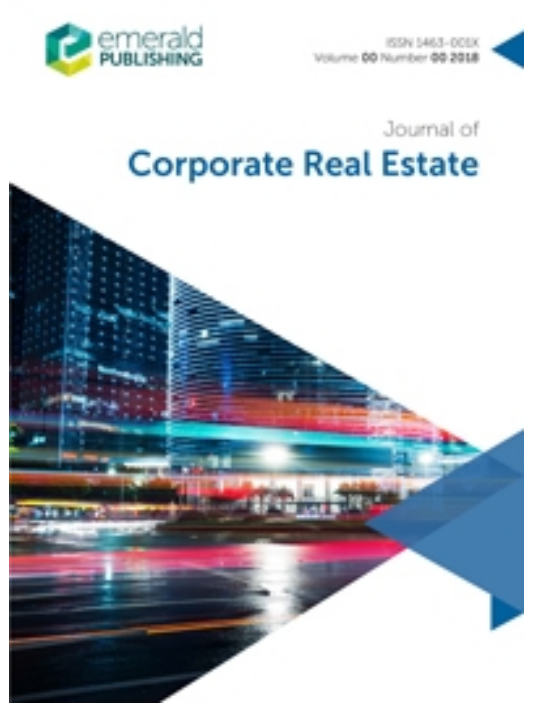

\section{BUSINESS MODELS IN FACILITIES MANAGEMENT VALUE CHAINS}

\begin{tabular}{|r|l|}
\hline Journal: & Journal of Corporate Real Estate \\
\hline Manuscript ID & JCRE-07-2019-0034.R1 \\
\hline Manuscript Type: & Research Paper \\
\hline Keywords: & $\begin{array}{l}\text { Value chains, Sourcing strategies, Business models, Maturity, } \\
\text { Archetypes, Facilties Management }\end{array}$ \\
\hline
\end{tabular}

\section{SCHOLARONE ${ }^{\text {M }}$ \\ Manuscripts}




\title{
BUSINESS MODELS IN FACILITIES MANAGEMENT VALUE CHAINS
}

\begin{abstract}
Purpose: To identify typical sourcing strategies and business models in Facilities Management (FM) and map archetypes of value chains with complementary sourcing strategies and value chains.

Methodology: The paper is based on literature and case studies from previous research. Theoretically, the paper takes a generic value chain as a starting point together with the recent ISO standard on sourcing process and a business model framework. A conceptual framework is developed and typical sourcing strategies and business models for FM are investigated. Archetypical values chains are established by a combination of sourcing strategies and business models.
\end{abstract}

Findings: The paper identify 8 archetypes of FM value chains divided in three groups according to whether the core business organisation occupy rented facilities, occupy owned facilities or has facilities operation as a core business like serviced office providers etc.

Implications: The results can be used on a general level by everybody, who need to get an overview and understanding of the complex structure of the FM sector. Furthermore, the results can help all parties involved in the FM value chain to get a clearer understanding of their position in the chain and help them develop their sourcing strategies and/or business model, depending on their type of organisation.

Originality: While there is a huge amount of literature on sourcing in FM, the business models and value chains have only be limited researched. The paper is original in combining an investigation of sourcing strategies, business models and value chains in FM.

Keywords: Facilities Management, value chain, sourcing strategies, business models, maturity, archetypes

\section{Paper type: Conceptual}

\section{Introduction}

During the last decades, the interest in business models has become evident in business management literature and research into business models has also become important. A main reason for this interest has been the introduction of the internet and other ICT technologies, which have created the possibility to develop many new types of business models, including new disruptive innovations and related business model.

However, within the field of Facilities Management (FM) there has been very little research on business models. One example is a study of business models in connection to university campus management in Finland (Rytkönen and Nenonen, 2014). Another example is a study of business model innovation in a Danish biotech company (Nardelli, 2018). Business models are closely related to value chains, and this is another topic, where there only has been limited research within FM. 
On the other side, sourcing has had much attention in FM research, particularly concerning outsourcing and decisions about what services to provide in-house and what services to provide by external companies (i.e. Ikediashi et al, 2014; Lok and Baldry, 2015; Plane and Green, 2011; Redlein and Zobl, 2014). This obviously have to do with FM being a demand driven sector, where the client og in-house FM organisation via their sourcing strategies set the conditions for external providers - even though the external providers by their marketing activities try to influence the decisions. In that way, sourcing strategies, business models and value chains are closely connected in FM.

The term 'FM sector' is used in the paper, as FM is not just an industry branch consisting of a conglomeration of companies within the same field. The FM sector is centred on specific work activities in companies in combination with markets and service providers and a superstructure with professional bodies and academic institutions (Andersen et al., 2014).

The question in focus of this paper is how sourcing strategies, business models and value chains are connected and typical combinations of these three interrelated elements. Thus, the purpose is to identify typical sourcing strategies and business models and map archetypes of value chains with complementary sourcing strategies and value chains in FM.

The paper is conceptual and draws on literature reviews and a number of case studies from previous research with a combination of the author's own research from the Nordic countries in Europe and case studies from various European countries presented in literature by other authors (i.e. Coenen and Nwanna, 2014; Katchamart, 2013a; Nardelli and Broumels, 2018). Therefore, the paper does not include a separate methods section. The reviewed literature is a combination of sources from the author's earlier research on FM, including sourcing strategies and business model, as well as reviews of the general literature on value chains conducted as part of an ongoing research project concerning business models in relation to sustainable building renovation and the construction value chain (Berg et al., 2019).

The paper reviews theory on value chains, sourcing strategies and business models in section 2 , which results in a conceptual model used in the further analysis. Section 3 presents the method of analysis together with analysis and findings. The paper finishes with discussion in section 4 and conclusion in section 5 .

\section{Theory and conceptual framework}

\subsection{Value chains}

The concept of value chain has been important in business management since Michael Porter introduced a generic value chain in his seminal book on Competitive Advantage (Porter, 1985). Porter's value chain focused on the activities inside a company, but the concept has later been used also for chains of different companies, where output from one part of the chain functions as input to the next part with the customer as the final part.

Porter's generic value chain does not specifically address FM, but it does distinguish between primary activities and support activities, where the primary activities are directly involved in creating value for the external customers, while the secondary activities create value internally. 
Thus, both primary and support activities are necessary elements in creating value. FM usually is seen as a support activity.

Jensen (2011) made an analysis of the relation between FM and core business in a Danish broadcasting corporation, which had applied Porter's generic model to define their value chain. The analysis found that besides the horizontal value chain of the core business, a separate related vertical FM value chain could be identified, which supported all the other internal parts in the value chain.

Scupola (2019) analysed the FM value chain in a study of the use of IT in FM. This resulted in the value chain model shown in Figure 1, which distinguish between the basic horizontal FM value chain with external providers, that deliver facilities service to in-house FM, who supports core business at the top and ICT-suppliers and consultant at the bottom. Suppliers and consultants can deliver IT-solution and consultancy services to all parts in the basic FM value chain. Different suppliers and consulting companies may deliver to each part in the basic value chain, so they are shown for each part as a vertical value chain. The basic horizontal FM value chain at the top in Figure 1 is the basis for the analysis in this paper.

Figure 1. The FM Value Chain (Scupola, 2019)

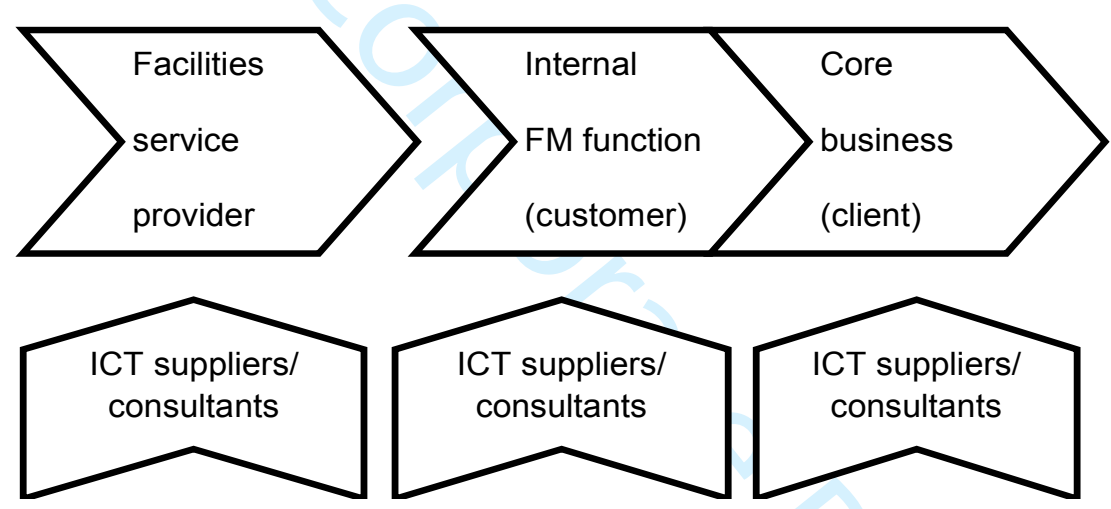

\subsection{Sourcing strategies}

Sourcing is an essential part of FM and much have been written about outsourcing versus in-house provision and different types of outsourcing (i.e. Ikediashi et al, 2014; Lok and Baldry, 2015; Plane and Green, 2011; Redlein and Zobl, 2014). There has even been an international standard published, which includes guidelines for strategic sourcing (ISO, 2016). The standard is structured according to a sequential sourcing model with the following 10 main phases:

1. Sourcing strategy and core business context

2. Identify current and future needs

3. Translate needs into requirements

4. Describe the Service Levels

5. Identify service delivery options

6. Business case development

7. Select preferred sourcing/service delivery option

8. Facilities service provision

- Internal service provision 
- External service provision

9. FM service procurement \& FM Agreement

10. Measure service provision performance

Jensen (2017) studied the strategic sourcing process in a Danish case organisation and compared it with the process in the ISO standard. It showed that the process in the case organisation had less phases and more parallel activities in developing the sourcing and procurement strategy. The main problem with the standard is that it is based on the sequential model starting with detailing the demand and needs before investigating sourcing option. The case showed that the ways, needs are specified in tender material depends on the chosen sourcing models. However, the standard has a sound approach to strategic sourcing being open to combining internal and external service provisions.

Sourcing is theoretically related to the classical corporate management question of making or buying and related to this, coordination based on corporate organisation (hierarchy) or market (Williamson, 2008). The question can be seen as a narrow and short-term economical question of finding the cheapest solution, but it can also be regarded as a strategic issue, where long-term benefits and risks are more in focus. As many organisations have achieved increased experience with outsourcing of FM, the strategic view seems to become more important. Vitasek (2016) investigated 'strategic sourcing business models', but not particularly in relation to FM.

\subsection{Business models}

A business model describes, what value a business provides to its customers, how it create the value, and how it generate income. There are many definitions of business models. Fielt (2013) analysed such definitions and concluded, "We define a business model as a representation of the value logic of an organization in terms of how it creates value and captures customer value". Teece (2010) claims that a business model is more generic than a business strategy. However, it is necessary to couple strategy and business model analysis to protect competitive advantage resulting from new business model design. Patenting products and processes can be an effective way to protect business models, but Teece (2010) also points to co-specialisation as a way to create competitive advantages by having key resources and processes developed together over time to create a unique and valuable combination.

One of the most widely used frameworks for analysing and developing business models is the Business Model Canvas (Osterwalder and Pigneur, 2010), which also was used in the earlier mentioned study by Rytkönen and Nenonen (2014). However, the Business Model Canvas includes many different elements and can be complicated to use in research across organisations as experienced by Berg et al. (2017). Therefore, this paper applies the simpler four-block framework by Christensen et al. (2016). The framework includes Priorities divided in Value proposition and Profit formula and Capabilities divided in Resources and Processes as shown in Table 1. The authors stress that the interrelationships and balance between the four blocks are essential. The value proposition is the first among equals and is the central dimension of a business model as stated by Fielt (2013). 


\subsection{Conceptual framework}

In this paper, sourcing strategies and business models are seen as complementary, where sourcing strategies are related to the demand side and business models are related to the supply side. Thus, between each part of the value chain there is a connection to neighbouring parts consisting of a sourcing strategy and one or more business models depending on the sourcing strategy. This is shown in Figure 2, which includes an elaboration of the basic horizontal FM value chain in Figure 1. Core business on the right is the ultimate customer, while the chain can be continued to the left with different levels of sub-providers. In this paper, sub-providers will only be addressed as part of the analysis of the other parts.

Figure 2: The FM Value Chain with complementary sourcing strategies and business models

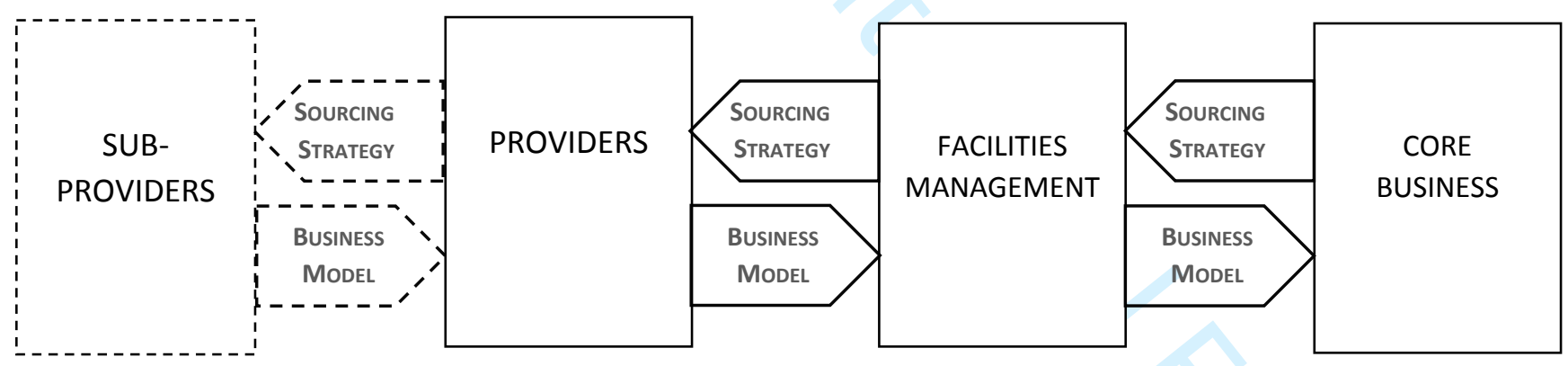

\section{Analysis and findings}

\subsection{Sourcing strategies}

There are a number of different options for sourcing in relation to FM both for the core business and for an in-house FM organisation.

For core business, the basic question is, whether FM should be provided centrally by a special FM organisation or de-centrally by each department or business unit. Except for very small businesses, it is has increasingly become common to establish a special FM organisation. The FM organisation can be in-house with different positions in the corporate structure. It can be an internal staff function, which typically is managed as a cost centre, or it can be a line organisation in which case 
it possibly can be a profit centre with internal rent and debiting (Kaiser, 1989; Jensen, 2008a). FM can also be part of a shared service centre together with other support function, which is shown in a case study concerning public organisations in the Netherlands (Katchamart, 2013a). A solution mainly used by large corporations with subsidiary companies is to establish a sub-subsidiary FM company operating on more or less commercial conditions. Two case studies of this are included in Jensen et al. (2008) - one from Denmark and one from Sweden.

Furthermore, there are solutions with integrated space and service provision like serviced offices, incubators and co-working spaces. Jensen et al. (2008) present two case studies of this - an international case of an office hotel company and a case of an incubator at a university in Denmark and Van Meel (2015) presents three case studies of co-work offices from Amsterdam, Copenhagen and Paris. A special option for public organisations is provision of space and services in new buildings via Public-Private Partnership (Kristiansen, 2019).

For in-house FM organisations, the basic question is to which degree services should be provided in-house or by external providers. In most cases the solution will be a combination. The external provision can take place as out-tasking of single services, outsourcing of bundled services or an integrated delivery of most services. The latter solution is sometimes called I-FM (Integrated FM) or T-FM (Total FM), but in this paper it is called I-FS (Integrated Facilities Services). Text and reference books on FM like Jensen (2008a) and Wiggins (2010) generally cover the mentioned sourcing solutions.

\subsection{Business models}

There is a number of typical business models (BM's) both for in-house FM organisations and for providers.

\section{BM's for in-house FM (BM-IH)}

For in-house FM, a possible solution is to establish a contract management organisation, which do not provide any operational service, but on the core business (CB) is in charge of managing contracts with one or more external providers - often an I-FS contract with one provider company. Such a contract management organisation is sometimes called 'the intelligent client' (Williams, 1989; Wiggins, 2010) or the 'informed client' (Atkins and Brooks, 2009).

To identify other solutions based on developing an in-house FM organisation with some internal service provision, maturity models for FM have been studied as part of this research. Several such maturity models have been developed. In the related field of CREM (Corporate Real Estate Management), Joroff et al. (1993) early on developed a very influential model. For this paper, the author has used a combination of two models developed for public FM organisations in Denmark. One was developed in connection to establishing a property centre in Copenhagen Municipality and it is described in a case study (Jensen et al., 2008). The other was developed as part of consultancy report from a management consulting company about generally improving FM in Danish municipalities (EY, 2017). Both maturity models include five levels. Table 2 presents the results of an analysis of the five maturity levels and the contract management solution based on the four block BM framework by Christensen et al. (2016). 


\begin{tabular}{|c|c|c|c|c|}
\hline Business model & Value proposition & Profit formula & Resources & Processes \\
\hline $\begin{array}{l}\text { BM-IH1: } \\
\text { Caretaker/ } \\
\text { Limiting cost }\end{array}$ & $\begin{array}{l}\text { Basic offering: } \\
\text { - Basic facilities } \\
\text { services } \\
\text { Additional: } \\
\text { - Minor building } \\
\text { works }\end{array}$ & $\begin{array}{l}\text { Basic offering: } \\
\text { - Budget allocation } \\
\text { (cost centre) } \\
\text { Additional: } \\
\text { - Refund of external } \\
\text { cost of building } \\
\text { work }\end{array}$ & 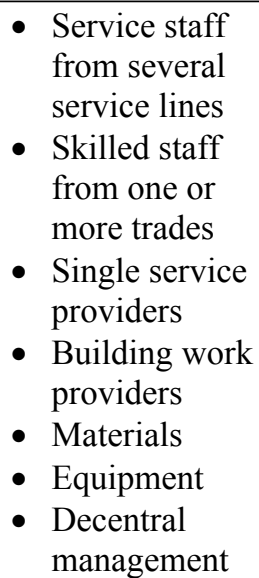 & $\begin{array}{l}\text { - Service operations } \\
\text { and craft based } \\
\text { operations according } \\
\text { to norms and } \\
\text { management } \\
\text { instructions } \\
\text { - Input and transaction } \\
\text { oriented contracts } \\
\text { with providers } \\
\text { - Cost focus and no } \\
\text { defined policies }\end{array}$ \\
\hline $\begin{array}{l}\text { BM-IH2: } \\
\text { Building } \\
\text { owner/ } \\
\text { Operational } \\
\text { efficiency }\end{array}$ & $\begin{array}{l}\text { Basic offering: } \\
\text { - Basic facilities } \\
\text { services } \\
\text { - Basic space } \\
\text { management } \\
\text { Additional: } \\
\text { - Building works }\end{array}$ & $\begin{array}{l}\text { Basic offering: } \\
\text { - Budget allocation } \\
\text { (cost centre) or } \\
\text { income from } \\
\text { internal rent and } \\
\text { debiting (profit } \\
\text { centre) } \\
\text { Additional: } \\
\text { - Refund of external } \\
\text { cost of building } \\
\text { work }\end{array}$ & $\begin{array}{l}\text { As above plus } \\
\text { central } \\
\text { management } \\
\text { plus } \\
\text { - Technicians }\end{array}$ & $\begin{array}{l}\text { As above plus } \\
\text { - Minor planning } \\
\text { activities and } \\
\text { dialogue with client } \\
\text { - Standardisation of } \\
\text { service levels and } \\
\text { contracts } \\
\text { - Cost and possibly } \\
\text { also income focus }\end{array}$ \\
\hline $\begin{array}{l}\text { BM-IH3: } \\
\text { Active building } \\
\text { owner/ } \\
\text { Flexibility }\end{array}$ & $\begin{array}{l}\text { Basic offering: } \\
\text { - Facilities services } \\
\text { - Technical } \\
\text { monitoring } \\
\text { - Space management } \\
\text { Additional: } \\
\text { - Building works } \\
\text { - Internal consulting }\end{array}$ & $\begin{array}{l}\text { Basic offering: } \\
\text { - Budget allocation } \\
\text { (cost centre) or } \\
\text { income from } \\
\text { internal rent and } \\
\text { debiting (profit } \\
\text { centre) } \\
\text { Additional: } \\
\text { - Refund of external } \\
\text { cost of building } \\
\text { work }\end{array}$ & $\begin{array}{l}\text { As above plus } \\
\text { - Bundling of } \\
\text { some services } \\
\text { - Monitoring } \\
\text { - } \text { Systems } \\
\text { - Consultants }\end{array}$ & $\begin{array}{l}\text { - Service operations } \\
\text { and craft based } \\
\text { operations based on } \\
\text { SLAs with some } \\
\text { output based } \\
\text { contracts } \\
\text { - Building work based } \\
\text { on project } \\
\text { specifications } \\
\text { - Technical analyses, } \\
\text { planning, monitoring } \\
\text { with a focus on } \\
\text { optimisation } \\
\text { - Dialogue with client } \\
\text { and customers } \\
\end{array}$ \\
\hline $\begin{array}{l}\text { BM-IH4: } \\
\text { Preferred } \\
\text { partner/ } \\
\text { Proactivity }\end{array}$ & $\begin{array}{l}\text { Basic offering: } \\
\text { - Facilities services } \\
\text { - Technical } \\
\text { monitoring } \\
\text { - Space management } \\
\text { - User feedback } \\
\text { Additional: } \\
\text { - Building works } \\
\text { - Internal consulting }\end{array}$ & $\begin{array}{l}\text { Basic offering: } \\
\text { - Income from } \\
\text { internal rent and } \\
\text { debiting (profit } \\
\text { centre) } \\
\text { Additional: } \\
\text { - Refund of external } \\
\text { cost of building } \\
\text { work }\end{array}$ & $\begin{array}{l}\text { As above plus } \\
\text { - Helpdesk }\end{array}$ & $\begin{array}{l}\text { As above plus } \\
\text { - Focus on portfolio } \\
\text { development and } \\
\text { added value } \\
\text { - Dialogue with client, } \\
\text { customers and end- } \\
\text { users as wells as } \\
\text { collaboration with } \\
\text { other support } \\
\text { functions } \\
\text { - Perhaps outcome } \\
\text { based contracts. }\end{array}$ \\
\hline $\begin{array}{l}\text { BM-IH5: } \\
\text { Innovator/ } \\
\text { Strategic value } \\
\text { creating }\end{array}$ & $\begin{array}{l}\text { Basic offering: } \\
\text { - Facilities services } \\
\text { - Technical } \\
\text { monitoring }\end{array}$ & $\begin{array}{l}\text { Basic offering: } \\
\text { - Income from } \\
\text { internal rent and }\end{array}$ & $\begin{array}{l}\text { As above plus } \\
\text { - Strategic } \\
\text { partnerships }\end{array}$ & $\begin{array}{l}\text { As above plus } \\
\text { - Focus on } \\
\text { development of the } \\
\text { market }\end{array}$ \\
\hline
\end{tabular}




\begin{tabular}{|c|c|c|c|c|}
\hline & $\begin{array}{l}\text { - Space management } \\
\text { - User feedback } \\
\text { Additional: } \\
\text { - Building works } \\
\text { - Internal consulting } \\
\text { - Joint development } \\
\text { projects with CB }\end{array}$ & $\begin{array}{l}\text { debiting (profit } \\
\text { centre) } \\
\text { Additional: } \\
\text { - Refund of external } \\
\text { cost of building } \\
\text { work and } \\
\text { development } \\
\text { projects }\end{array}$ & $\begin{array}{l}\text { with external } \\
\text { providers. } \\
\text { - R\&D partners }\end{array}$ & $\begin{array}{l}\text { - R\&D projects and } \\
\text { innovation }\end{array}$ \\
\hline $\begin{array}{l}\text { BM-IH6: } \\
\text { Contract } \\
\text { management }\end{array}$ & $\begin{array}{l}\text { Basic offering: } \\
\text { - Procuring and } \\
\text { controlling a } \\
\text { contract with an I- } \\
\text { FS provider, who } \\
\text { delivers all } \\
\text { facilities services } \\
\text { and related } \\
\text { planning and } \\
\text { management }\end{array}$ & $\begin{array}{l}\text { Basic offering: } \\
\text { - Budget allocation } \\
\text { (cost centre) }\end{array}$ & $\begin{array}{l}\text { - I-FS provider } \\
\text { - Contract } \\
\text { manager } \\
\text { - Supervisors } \\
\text { - Consultants } \\
\text { - Legal advisors }\end{array}$ & $\begin{array}{l}\text { - Governing, } \\
\text { managing and } \\
\text { supervising external } \\
\text { provision } \\
\text { - Dialogue with client } \\
\text { and customers }\end{array}$ \\
\hline
\end{tabular}

Table 2. Analysis of BM's for in-house FM organisations (BM-IH)

BM-IH1, Caretaker/Limiting cost, is the most basic, where the value proposition is just to sustain the core business with necessary facilities services with no ambitions of improving the core business. Besides the basic facilities services, minor building works can be included in the offering. The profit formula is typically a budget allocation to a cost centre for the basic service and refund of external cost for additional building works. In-house resources mostly include Service staff from several service lines (soft services) and Skilled staff from one or more trades (hard services) and a decentral management, which may not have a special FM qualifications. Besides, the organisation procure external single service providers, building work providers, materials and equipment. The processes include service operations and craft based operations according to norms and management instructions. Contracts with providers are typical with transaction oriented input based specifications. Decision-making mostly has cost focus without any defined policies.

BM-IH2, Building owner/Operational efficiency, is also rather basic with a similar value proposition, but include a stronger focus on space planning. Thus, basic space management is included in the offering. The profit formula can be the same, but it also be based on income from internal rent and debiting (profit centre). Technicians are added to the resources and the processes further include minor planning activities and dialogue with client, standardisation of service levels and contracts. Management of FM is centralised and beside the focus on cost in decision-making, an income focus might be included.

BM-IH3, Active building owner/Flexibility, also has a similar value proposition, but with a stronger focus on professional and technical oriented management. Thus, technical monitoring and possibly internal consulting, is included in the offering. The profit formula is the same as BM-IH2, but to the resources are added bundling of some services, monitoring systems and use of consultants. The processes include service operations and craft based operations based on Service Level Agreements (SLAs) with some output-based contracts, building work based on project specifications, technical analyses, planning, monitoring with a focus on optimisation and dialogue with client and customers. 
BM-IH4, Preferred partner/Proactivity, is characterised by a focus on not just sustaining but also attempts to improve the core business. Thus, responsiveness to user feedback in included in the offering. The basic profit formula is based on income from internal rent and debiting (profit centre). A helpdesk is added to resources and to processes are added a focus on portfolio development and added value, dialogue with client, customers and end-users as wells as collaboration with other support functions and perhaps use of outcome based contracts.

BM-IH5, Innovator/Strategic value creating, has an even stronger focus on improving the core business and creating joint innovations and development. Thus, joint development projects are added to the additional offering. The profit formula is the same as BM-IH4 except for adding possibly refunding of cost of development projects. To resources are added strategic partnerships with external providers and collaboration with R\&D partners and to processes are added focus on development of the market and R\&D projects and innovation.

BM-IH6, Contract management, is fundamentally different by a value proposition with the basic offering to procure and control a contract with an I-FS provider, who delivers all facilities services and related planning and management. This can be based on a pure cost focus, but it can also be based on quality and joint development in a strategic partnership, depending on the priority of the core business. The profit formula for contract management is a budget allocation (cost centre) to cover the in-house cost as well as payments to the I-FS provider and other external cost. The resources are mainly the contractor manager, supervisors and the I-FS provider, but other external partners like consultants and legal advisors could also be involved for specific assignments. The main processes are governing, managing and supervising external provision as well as dialogue with client and customers.

\section{BM's for providers}

For providers it was found appropriate to distinguish between the more general service providers to FM and providers specifically targeting building owners with main focus on building related services - also called 'hard FM'.

The BM's for service providers (BM-SP) more or less mirrors the sourcing options for in-house FM organisations. They include provision of single service, bundled service and I-FS. These are models where services typically are procured by tendering with price competitions. An additional option is management contracting, where a management consultant company takes responsibility for organising the service provision by external providers based on a management fee, incentive based bonus fees and reimbursement of the cost of the service provision. Nardelli and Broumels (2018) did a case study on FM innovation concerning an energy supply company in the Netherlands, which involved a managing contractor. Table 3 presents the results of an analysis of those four business models for service providers and management consultants.

\begin{tabular}{|c|c|c|c|c|}
\hline Business model & Value proposition & Profit formula & Resources & Processes \\
\hline $\begin{array}{l}\text { BM-SP1: } \\
\text { Single service }\end{array}$ & $\begin{array}{l}\text { Basic offering: } \\
\text { - Specialised service } \\
\text { delivered regularly } \\
\text { on the client's sites } \\
\text { for a contract } \\
\text { period } \\
\text { Additional: }\end{array}$ & $\begin{array}{l}\text { Basic offering: } \\
\text { - Fixed price } \\
\text { Additional: } \\
\text { - Hourly rates or } \\
\text { agreed price }\end{array}$ & $\begin{array}{l}\text { - } \text { Specialised } \\
\text { staff from one } \\
\text { service line } \\
\text { - Materials } \\
\text { - Equipment } \\
\text { - } \text { Management }\end{array}$ & $\begin{array}{l}\text { - Standardised service } \\
\text { operations based on } \\
\text { SLA's, norms } \\
\text { and/or management } \\
\text { instructions }\end{array}$ \\
\hline
\end{tabular}




\begin{tabular}{|c|c|c|c|c|}
\hline & $\begin{array}{l}\text { - Related extra } \\
\text { service on order }\end{array}$ & & & \\
\hline $\begin{array}{l}\text { BM-SP2: } \\
\text { Bundled } \\
\text { services }\end{array}$ & $\begin{array}{l}\text { Basic offering: } \\
\text { - Two or more } \\
\text { specialised services } \\
\text { delivered regularly } \\
\text { on the client's sites } \\
\text { for a contract } \\
\text { period } \\
\text { - One point of } \\
\text { contact } \\
\text { Additional: } \\
\text { - Related extra } \\
\text { service on order }\end{array}$ & $\begin{array}{l}\text { Basic offering: } \\
\text { - Fixed price } \\
\text { Additional: } \\
\text { - Hourly rates or } \\
\text { agreed price }\end{array}$ & $\begin{array}{l}\text { - } \text { Specialised } \\
\text { staff from two } \\
\text { or more service } \\
\text { lines } \\
\text { - } \text { Materials } \\
\text { - Equipment } \\
\text { - } \text { Management }\end{array}$ & $\begin{array}{l}\text { As above plus } \\
\text { - Coordination of } \\
\text { service provision }\end{array}$ \\
\hline $\begin{array}{l}\text { BM-SP3: } \\
\text { I-FS }\end{array}$ & $\begin{array}{l}\text { Basic offering: } \\
\text { - Several specialised } \\
\text { services delivered } \\
\text { regularly on the } \\
\text { client's sites for a } \\
\text { contract period } \\
\text { - One point of } \\
\text { contact } \\
\text { - Annual cost } \\
\text { reductions } \\
\text { - Improvement } \\
\text { proposals } \\
\text { Additional: } \\
\text { - Related extra } \\
\text { service on order }\end{array}$ & $\begin{array}{l}\text { Basic offering: } \\
\text { - Fixed price with } \\
\text { annual adjustment } \\
\text { - Bonus incentives } \\
\text { and gain sharing } \\
\text { Additional: } \\
\text { - Hourly rates or } \\
\text { agreed price } \\
\text { - Claims from } \\
\text { deficiencies in } \\
\text { contract } \\
\text { specifications }\end{array}$ & $\begin{array}{ll}\text { - } & \text { Specialised } \\
\text { staff from } \\
\text { several service } \\
\text { lines } \\
\text { - Technicians } \\
\text { - Sub-providers } \\
\text { - Materials } \\
\text { - Equipment } \\
\text { - Management }\end{array}$ & $\begin{array}{l}\text { As above plus } \\
\text { - Ongoing reporting, } \\
\text { governance, } \\
\text { improvements and } \\
\text { consulting }\end{array}$ \\
\hline $\begin{array}{l}\text { BM-SP4: } \\
\text { Management } \\
\text { contracting }\end{array}$ & $\begin{array}{l}\text { Basic offering: } \\
\text { - Responsibility for } \\
\text { several specialised } \\
\text { services delivered } \\
\text { regularly on the } \\
\text { client's sites for a } \\
\text { contract period } \\
\text { - One point of } \\
\text { contact } \\
\text { - Annual cost } \\
\text { reductions } \\
\text { - Improvement } \\
\text { proposals } \\
\text { Additional: } \\
\text { - Related extra } \\
\text { service on order }\end{array}$ & $\begin{array}{l}\text { Basic offering: } \\
\text { - Fixed management } \\
\text { fee } \\
\text { - Bonus incentives } \\
\text { - Direct cost for } \\
\text { service provision is } \\
\text { refunded } \\
\text { Additional: } \\
\text { - Direct cost for extra } \\
\text { service is refunded } \\
\text { - Hourly rates or } \\
\text { agreed price for } \\
\text { additional } \\
\text { management tasks }\end{array}$ & $\begin{array}{l}\text { - } \text { Management } \\
\text { consultants } \\
\text { - Supervisors } \\
\text { - Technicians } \\
\text { - Providers } \\
\text { - Management }\end{array}$ & $\begin{array}{l}\text { - Management of } \\
\text { standardised service } \\
\text { operations based on } \\
\text { SLA's } \\
\text { - Ongoing reporting, } \\
\text { governance, } \\
\text { improvements and } \\
\text { consulting }\end{array}$ \\
\hline
\end{tabular}

Table 3. Analysis of BM's for service providers to in-house FM organisations (BM-PS)

BM-SP1, Single service, involves a value proposition with a basic offering of specialised service delivered regularly on the client's sites for a contract period with the additional possibility of related extra service on order. The profit formula is typically based on a fixed price for the basic offering and payment according to hourly rates or agreed price for extra service. Resources are specialised staff from one service line, materials equipment and management. Processes are mostly standardised service operations based on SLA's, norms and /or management instructions. 
BM-SP2, Bundled services, resembles BM-SP1, but the value proposition is with a basic offering of two or more specialised services - instead of just one - delivered regularly on the client's sites for a contract period and with one point of contact. The profit formula is the same. Resources also include specialised staff from two or more service lines instead of just from one. To processes is added coordination of service provision.

BM-SP3, I-FS, is more complex. The value proposition includes several specialised services delivered regularly on the client's sites for a contract period with one point of contact, annual cost reductions and improvement proposals and as for the former BM-SP's, additionally extra service on order. The profit formula includes fixed price with annual adjustment related to bonus incentives and gain sharing as well as additionally payment of extra service according to hourly rates or agreed price and as a new and in some cases important aspect; claims from deficiencies in contract specifications. Resources include specialised staff from several service lines, technicians, subproviders, materials, equipment and management. The processes include the same as BM-SP2 with addition of ongoing reporting, governance, improvements and consulting.

BM-SP4, Management contracting, is in principle very different in the value proposition and profit formula, but in other ways, it resembles I-FS with an integrated delivery. The basic offering includes responsibility for several specialised services delivered regularly on the client's sites for a contract period, one point of contact, annual cost reductions and improvement proposals and additionally extra service on order. The profit formula includes fixed management fee, bonus incentives and refunding direct cost for service provision and additionally refunding of direct cost for extra service provision and payment for additional management tasks according to hourly rates or agreed price. Resources include management consultants, supervisors, technicians, providers and management. Processes include management of standardised service operations based on SLA's and ongoing reporting, governance, improvements and consulting.

The BM's for providers targeting building owners (BM-BO) are divided in providers of building work like maintenance, real estate administrations and ESCO (Energy Service Companies). Table 4 presents the results of an analysis of those three BM's.

\begin{tabular}{|c|c|c|c|c|}
\hline Business model & Value proposition & Profit formula & Resources & Processes \\
\hline $\begin{array}{l}\text { BM-BO1: } \\
\text { Building work }\end{array}$ & $\begin{array}{l}\text { Basic offering: } \\
\text { - Specialised services } \\
\text { delivered on a } \\
\text { project basis at the } \\
\text { client's sites } \\
\text { Additional: } \\
\text { - Related extra } \\
\text { service on order }\end{array}$ & $\begin{array}{l}\text { Basic offering: } \\
\text { - Fixed price } \\
\text { Additional: } \\
\text { - Hourly rates or } \\
\text { agreed price } \\
\text { - Claims from } \\
\text { deficiencies in } \\
\text { project } \\
\text { specifications }\end{array}$ & $\begin{array}{l}\text { - Skilled staff } \\
\text { from one or } \\
\text { more trades } \\
\text { - Technicians } \\
\text { - Materials } \\
\text { - Equipment } \\
\text { - } \text { Management }\end{array}$ & $\begin{array}{l}\text { Craft based } \\
\text { operations according } \\
\text { to project } \\
\text { specifications }\end{array}$ \\
\hline $\begin{array}{l}\text { BM-BO2: } \\
\text { Real estate } \\
\text { administration }\end{array}$ & $\begin{array}{l}\text { Basic offering: } \\
\text { - Rent out space for } \\
\text { building owners } \\
\text { and collect rent } \\
\text { from tenants } \\
\text { Additional: } \\
\text { - Operation and } \\
\text { maintenance } \\
\end{array}$ & $\begin{array}{l}\text { Basic offering: } \\
\text { - Fee as a fixed } \\
\text { percentage of rent } \\
\text { income for rent } \\
\text { administration } \\
\text { Additional: } \\
\text { - Fee as a fixed } \\
\text { percentage of rent }\end{array}$ & $\begin{array}{l}\text { - Economist } \\
\text { - Lawyers } \\
\text { - Technicians } \\
\text { - Caretakers and } \\
\text { service staff } \\
\text { - Supervisors } \\
\text { - Sub-providers } \\
\text { - Management } \\
\end{array}$ & $\begin{array}{l}\text { - Administrative } \\
\text { processes; possibly } \\
\text { supplemented with: } \\
\text { - Service operations } \\
\text { - Craft based } \\
\text { operations } \\
\text { - Project management } \\
\text { - Consulting }\end{array}$ \\
\hline
\end{tabular}




\begin{tabular}{|c|c|c|c|c|}
\hline & $\begin{array}{l}\text { - Rebuilding and } \\
\text { refurbishment } \\
\text { - Real estate } \\
\text { development } \\
\text { - Consultancy }\end{array}$ & $\begin{array}{l}\text { income for } \\
\text { operation and } \\
\text { maintenance } \\
\text { - Hourly rates or } \\
\text { agreed price for } \\
\text { projects and } \\
\text { consultancy }\end{array}$ & & \\
\hline $\begin{array}{l}\text { BM-BO3: } \\
\text { ESCO }\end{array}$ & $\begin{array}{l}\text { Basic offering: } \\
\text { - Energy savings in a } \\
\text { portfolio of } \\
\text { buildings for the } \\
\text { building owner } \\
\text { Additional: } \\
\text { - Instruction of in- } \\
\text { house FM staff }\end{array}$ & $\begin{array}{l}\text { Basic offering: } \\
\text { - Fee based on } \\
\text { guaranteed energy } \\
\text { savings } \\
\text { Additional: } \\
\text { - Gain sharing from } \\
\text { additional savings } \\
\text { - Claims from } \\
\text { changes in baseline }\end{array}$ & $\begin{array}{l}\text { - } \text { Technicians } \\
\text { - Skilled staff } \\
\text { from different } \\
\text { trades } \\
\text { - Monitoring } \\
\text { systems } \\
\text { - Management }\end{array}$ & $\begin{array}{l}\text { - Craft based } \\
\text { operations and } \\
\text { technical analyses, } \\
\text { planning and } \\
\text { monitoring }\end{array}$ \\
\hline
\end{tabular}

Table 4. Analysis of BM's for providers targeting building owners (BM-BO)

BM-BO1, Building work, is characterised by a value proposition of specialised services delivered on a project basis at the client's sites and additionally extra service on order. The profit formula is as simple as fixed price often based on competitive tendering and additionally payment for extra service according to hourly rates or agreed price and as for BM-PS3 (I-IFS); claims from deficiencies in project specifications. Resources include skilled staff from one or more trades, technicians, materials, equipment and management and processes include craft based operations according to project specifications.

$\mathrm{BM}-\mathrm{BO} 2$, Real estate administration, is characterised by a value proposition of renting out space for building owners and collecting rent from tenants and additionally operation and maintenance, rebuilding and refurbishment, real estate development and consultancy. The profit formula is fee as a fixed percentage of rent income for rent administration and additionally fee as a fixed percentage of rent income for operation and maintenance payment according to hourly rates or agreed price for projects and consultancy. Resources include economist, lawyers, technicians, caretakers/service staff, supervisors, sub-providers and management. Processes includes administrative processes; possibly supplemented with service operations, craft based operations, project management and consulting.

$\mathrm{BM}-\mathrm{BO} 3, \mathrm{ESCO}$, represents a rather unique $\mathrm{BM}$. The value proposition is energy savings in a portfolio of buildings for the building owner and additionally instruction of in-house FM staff, while the profit formula is fee based on guaranteed energy savings and additionally gain sharing from additional savings and claims from changes in baseline. The resources include technicians, skilled staff from different trades, monitoring systems and management and the processes are craft based operations and technical analyses, planning and monitoring.

\subsection{Archetypes of FM value chains}

The FM value chain consists as described in section 2.1 of core business as the customer, which is supported by an internal FM organisation responsible for service provision; possibly with a combination of in-house provision and provision from external providers, who also can have subproviders. From the analysis it was found that FM value chains could be grouped according to the type of facilities and ownership of facilities that the core business occupy. It was found appropriate 
to group the value chains according to core businesses in rented facilities, own (owned) facilities and facilities operated to be used by other companies like serviced offices etc.

The distinction between rented and own facilities is not related to the formal financial arrangement but to who has the owner responsibility; particularly in relation to building maintenance and operation of the shell and basic technical infrastructure and for multi-user property also of shared facilities outdoor and indoor. Rented and own facilities are both typically related to situations, where staff in the company and possibly visitors are the end users.

Facility operators are seen as organisations, who have FM as integrated part of their core business. Here the end users typically are staff from customer companies for the operator or individual customers. For instance, shopping centre management companies are responsible for operating shopping centres and their direct customers are the shops, who rent space at the shopping centre, but the public using the shopping centre are customers for the shops. Thus, the public using the shops are customer's customers for the shopping centre management company, and their shopping experience is essential for the whole shopping centre as explained in a case study of a Danish shopping centre management company (Jensen et al., 2008).

The formal ownership is not important in this context for shopping centres and many other types of facilities operators, but when it comes to management of housing estate, ownership has a fundamental importance. According to an analysis by Nielsen et al. (2012) of the so-called strategic FM organisation in housing organizations under different types of ownership, a difference between a strong demand driven strategic management in social and cooperative housing associations and an increasingly stronger supply driven management in privately owned housing companies could be identified.

Table 5 presents an overview of eight archetypes of FM value chains divided in the three groups with the modification that the first group both can be relevant for rented and own facilities. For practical reasons, the value chains are shown in the opposite order than in Figure 1 and 2 starting with core business in the second column from left.

\begin{tabular}{|c|c|c|c|c|}
\hline $\begin{array}{l}\text { FM value } \\
\text { chain }\end{array}$ & Core business & FM & Providers & Sub-providers \\
\hline FM-VC1 & \multirow[t]{2}{*}{$\begin{array}{l}\text { Rented facilities or } \\
\text { Own facilities }\end{array}$} & $\begin{array}{l}\text { Caretaker/ } \\
\text { Limiting cost }\end{array}$ & Single service & \\
\hline FM-VC2 & & Contract manager & $\begin{array}{l}\text { Single } \\
\text { Bundled services } \\
\text { I-FS }\end{array}$ & Single service \\
\hline FM-VC3 & \multirow[t]{3}{*}{ Own facilities } & $\begin{array}{l}\text { Building owner/ } \\
\text { Operational efficiency }\end{array}$ & $\begin{array}{l}\text { Single service } \\
\text { Bundled services } \\
\text { Building work }\end{array}$ & \\
\hline FM-VC4 & & $\begin{array}{l}\text { Active building owner/ } \\
\text { Flexibility }\end{array}$ & $\begin{array}{l}\text { As above plus } \\
\text { Consultants } \\
\text { Legal advisors } \\
\text { ESCO }\end{array}$ & \\
\hline FM-VC5 & & $\begin{array}{l}\text { Preferred partner/ } \\
\text { Proactivity }\end{array}$ & $\begin{array}{l}\text { As above } o r \\
\text { I-FS or } \\
\text { Management } \\
\text { contractor }\end{array}$ & $\begin{array}{l}\text { If I-FS or Management } \\
\text { contractor: } \\
\text { Single service } \\
\text { Building work } \\
\text { Consultants }\end{array}$ \\
\hline
\end{tabular}




\begin{tabular}{|l|l|l|l|l|}
\hline \multirow{2}{*}{ FM-VC6 } & & & Legal advisors \\
\cline { 3 - 4 } & & $\begin{array}{l}\text { Innovator/ } \\
\text { Strategic value creating }\end{array}$ & $\begin{array}{l}\text { As above plus } \\
\text { R\&D partners }\end{array}$ & As above \\
\hline FM-VC7 & $\begin{array}{l}\text { Facilities operator } \\
\text { (serviced office providers, shopping centre, } \\
\text { airports, culture houses, housing associations, } \\
\text { PPPs etc.) }\end{array}$ & $\begin{array}{l}\text { Real estate } \\
\text { administration }\end{array}$ & $\begin{array}{l}\text { Single service } \\
\text { Bundled service } \\
\text { Building work } \\
\text { Consultants }\end{array}$ \\
\cline { 3 - 4 } & & $\begin{array}{l}\text { Single service } \\
\text { Fundled service } \\
\text { Building work }\end{array}$ & $\begin{array}{l}\text { Consultants } \\
\text { Legal advisors } \\
\text { ESCO }\end{array}$ & \\
& & ESCO & \\
\hline
\end{tabular}

Table 5. Typical FM value chains

Two value chains are the same for rented and own facilities. FM-VC1 includes an in-house FM organisation with focus on Caretaking/Limiting cost (BM-IH1) possibly withinvolvement of single service providers. FM-VC2 includes an in-house Contract Manager (BM-IH6), who engage single and/or bundled service providers. FM-VC1 and FM-VC2 are placed together and can both be seen as being on the lowest level of maturity with of focus on 'no frills' FM product as Katchamart (2013b) call the lowest level of complexity in his characterisation of FM products. However, contract management can be on a high level of sophistication particularly with I-FS solutions and thereby equivalent to one of the higher maturity levels for in-house FM organisations.

Besides FM-VC1 and FM-VC2, there are four value chains specifically for own facilities and they reflect the maturity models, which formed the main basis for Table 2. FM-VC3 is related to Building owner/Operational efficiency (BM-IH2), which might engage single service, bundled service and/or building work providers. FM-VC4 is related to Active building owner/Flexibility, which additionally might engage consultants, legal advisors and/or ESCO. FM-VC5 is related to Preferred partner/Proactivity, which might engage the same as FM-VC4 or an I-FS provider or a management contractor as well as various sub-providers. FM-VC6 is related to Innovator/Strategic value creating, which might engage R\&D partners in addition to those for FM-VC5.

Facilities operators are characterised by representing both core business and FM as FM is an integrated part of the core business. There are two value chains for facilities operators. FM-VC7 involves engaging a real estate administration, which might engage single service, bundled service and/or building worker sub-providers and/or consultants. FM-VC8 involves the facility operator directly engaging single service, bundled service and/or building work providers and possibly consultants, legal advisors and/or ESCO.

\section{Discussion}

\section{Origin of the different sourcing strategies and business models}

Contract management has existed for centuries and was developed to some sophistication during the Roman Empire as shown by Bröchner (2010). Caretaking probably has even longer historical roots and was in earlier historical times often undertaken by slaves. 
In modern times, out-tasking with single services initially was the dominant solution of external provision and often procured by negotiation without detailed requirement specifications and competitive tendering. An example is the cleaning contract between the Danish Broadcasting Corporation (DR) and ISS in the early 1990's had 50 years anniversary without ever having been in a competition. That possibility was abandoned by introduction of EU's procurement legislation for public clients and DR soon after had all cleaning service out for EU tendering resulting in drastic cost reductions as well as initial problems to obtain the required quality (Jensen, 2008b). Outsourcing with bundled services is relatively new phenomenon and has gradually developed as an extension of out-tasking/single services since the 1990's.

Managing contracts were introduced in the Nordic countries in 1995 by IBM's pan-European FM contract with Johnson Controls (Jensen, 2008a). This was followed in Sweden by the establishing of Skanska FM (now Coor Service Management) as a management consulting company in 1998, and they for instance started a long lasting collaboration with the Swedish telecommunication company L.M. Ericsson in 2000. The threat of being reduced to a sub-provider for management consultants resulted in ISS changing its strategy in 2000 from being a cleaning company towards becoming an I-FS provider. Case studies of these developments are included in Jensen et al. (2008).

For property investors, the collaboration with real estate administrations goes a long way back. Serviced offices and incubators mostly started after year 2000 and was later followed by coworking spaces.

Public-Private Partnerships were started in the UK by political decision in the 1980's during Margaret Thatcher's government. Iceland became the frontrunner for PPP in the Nordic country until it collapsed during the financial crisis from 2008. In Denmark, PPP was introduced after year 2000 on government initiative and the first project was a school building in Jutland starting in 2004 (Jensen et al., 2008). ESCO has a long history in some countries like Sweden and USA (Jensen et al., 2008), but ESCO was introduced in Denmark around 2008, when it started to be used by a number of municipalities (Nardelli et al., 2015).

\section{The characteristics of business models in the FM sector}

The presented business models are regarded as representing the most important types. Individual organisations will belong to one type, but their specific business model will have more details and not least, the capabilities and the relationships between the building blocks must have special characteristics for the company to create unique features and competitive advantage as pointed out by Teece (2010). However, the FM sector is a demand based sector. Thus, the demand side needs to set sourcing conditions for their providers, so that there is a sufficient number of provider companies that can comply with them. Similarly, the supply side needs to have business models that are general enough to be attractive to a sufficient number of different clients. This limits how unique the business models for FM providers can be.

Christensen et al. (2016) developed a life cycle model with three stages of business model's journey. It resembles the well-known product life cycle. They claim that business models over time become more resistant to change. However, this seems to be based on an analysis of supply based companies (like much international business management literature) that pushes products to a market, while for FM as demand based sector, client organisations pull service contracts via tendering from providers. Therefore, it could be hypothesized that business models in the FM sector are less tightly knit and more flexible in relation to modifications in accordance to changes in the 
market conditions. The FM relationship lifecycle model developed by Coenen and Nwanna (2014) might be more relevant for the FM sector than the mentioned BM life cycle model.

\section{Influencing factors}

The variety of value chains in the FM sector is an expression of the high complexity that characterises the sector. The value chains are strongly dependent on the facility solution that the core business make use of, but there are still more than one available value chain for each of the three main facilities solution. There are at least three factors influencing the choice of value chain and some likely influences are suggested in the following.

Company size: The larger an organisation is, the more likelihood there is of a more complex value chain or making use of more than one value chain.

Company complexity: The higher the complexity of a business, the more likelihood is over time to develop an FM organisation on a higher maturity level and make use of a more complex value chain. Office based companies will typically have a rather simple value chain, while more complex businesses like production companies, airports, hospitals, universities etc. probably will make use of more complex value chains.

Dynamics of the environment: This can influence in different ways and be related to the generic space strategies identified by O'Mara (1999):

- Companies in a fast changing and uncertain market, for instance start-ups, IT and consulting companies, are likely to follow an incremental strategy and apply a simple value chain with rented facilities

- Well consolidated companies under secure and expanding market conditions are likely to follow a standardisation strategy and make use of a complex value chain

- Companies with a value-based strategy are likely to reconsider their FM value chain to become aligned with the new values, which can have varying consequences depending on the views of the top management.

\section{Conclusion}

The purpose of this paper was to identify typical sourcing strategies and business models in Facilities Management (FM) and map archetypes of value chains with complementary sourcing strategies and value chains. The paper identified 8 archetypes of FM value chains divided in three groups according to whether the core business organisation occupy rented facilities, occupy owned facilities or has facilities operation as a core business like serviced office providers etc. While there is a huge amount of literature on sourcing in FM, the business models and value chains have only be limited researched. The novelty of the paper is the combination of investigating of sourcing strategies, business models and value chains in FM.

The results can be used on a general level by everybody, who needs to get an overview and understanding of the complex structure of the FM sector and how FM create value. This includes professional and trade associations, politicians and public authorities, teachers and researchers, top managers involved in decision-making concerning FM and strategists in organisations involved in the FM sector. The results can also help all parties involved in the FM value chain to get a clearer 
understanding of their position in the chain and help them further develop their sourcing strategies and/or business model, depending on their type of organisation.

The paper is conceptual, based on theory and case studies from previous research. The sourcing strategies are well documented, and the business models are at an overall level also well known, but the detailed analysis of the different business models could benefit from validation by other researchers and further empirical foundation. Most of the identified FM value chains much be regarded to have a preliminary character and need substantial validation.

\section{References}

Andersen, P.D., Andersen, A.D., Jensen, P.A. and Rasmussen, B. (2014), "Innovation-system foresight in practice. Nordic facilities management foresight". Futures, 61(September), pp. 33-44.

Atkins and Brooks (2009), Total Facilities Management, Third Edition, Wiley-Blackwell, Chichester, UK.

Berg, B.B., Thuesen, C., Ernstsen, S.K. and Jensen, P.A. (2019), "Constructing Archetypes: Mapping Business Models in the Construction Value Chain”. Working paper presented at ARCOM 2019 Conference, Leeds, UK, 2-4 September 2019.

Bröchner (2010), "Innovation and ancient Roman facilities management", Journal of Facilities Management 8(4), 246-255.

Christensen, C.M., Barman, T. and van Bever, D. (2016) "The Hard Thruth about Business Model Innovation”. MIT Sloan Management Review 58(11), pp. 30-30.

Coenen, C. and Nwanna, P. (2014), "Discovering the Relationship Lifecycle in FM: Phases and Driver of Costumer Value Perceptions", Proceedings of EFMC 2014 Conference and Research Symposium, Berlin, 4-6 June 2014.

EY (2017), Kortloegning af facility management i kommunerne. Ernst \& Young, Denmark.

Fielt, E. (2013), “Conceptualising Business Models: Definitions, Frameworks and Classification”, Journal of Business Models 1(1), pp. 85-105.

Ikediashi, D.I, and Ogunlana, S.O. and Boateng, P. (2014), "Determinants of outsourcing decision for facilities management (FM) services provision”, Facilities, 32(9/10), pp. 472-489.

ISO (2016), Facility Management - Part 2: Guidance on strategic sourcing and the development of agreements, International Standard ISO 41012, International Organization for Standardization.

Jensen, P.A. (2008a) Facilities Management for Practitioners and Students, Centre for Facilities Management - Realdania Research, DTU Management Engineering, Lyngby, Denmark

Jensen, P.A. (2008b), "The Origin and Constitution of Facilities Management as an Integrated Corporate Function", Facilities 26(13/14), pp. 490-500. 
Jensen, P.A. (2011), “Organisation of Facilities Management in relation to Core Business", Journal of Facilities Management 9(2), pp. 78-95.

Jensen, P.A. (2017), "Strategic Sourcing and Procurement of Facilities Management Services", Journal of Global Operations and Strategic Sourcing 10(2), pp. 138-158.

Jensen, P.A., Nielsen, K. and Nielsen, S.B. (2008), Facilities Management Best Practice in the Nordic Countries - 36 cases, Centre for Facilities Management - Realdania Research, DTU Management Engineering.

Joroff, M., Louargard, M., Lambert, S. and Becker, F. (1993), Strategic Management of the Fifth Resource: Corporate Real Estate Management, Industrial Development Research Foundation, USA.

Kaiser, H.H. (1989), Facilities Manager's Reference - Management, Planning, Building Audits, Estimating, R.S. Means Company, INC. Construction Consultants and Publishers, Kingston, MA, USA.

Katchamart, A. (2013a), Profiling Value Added Position in FM, PhD thesis 8.2013, DTU Management Engineering, Lyngby, Denmark.

Katchamart, A. (2013b), "Mapping value added positions in facilities management by using a product-process matrix” Journal of Facilities Management 11(3), pp. 226 - 252.

Kristiansen, K. (2019), Public-Private Partnerships and FM. Chapter in: Jensen, P.A. (ed.) "Facilities Management Models, Methods and Tools - Research results for practice". Routledge, Oxfordshire, UK.

Lok, K.A. and Baldry, D. (2015), "Facilities management outsourcing relationships in the higher education institutes", Facilities, 33(13/14), pp. 819-848.

Nardelli, G, and Rajala, R. (2018), "The evolution of facility management business models in supplier-client relationships" Journal of Facilities Management 16(1), pp. 38-53.

Nardelli, G. and Broumels, M. (2018), "Managing innovation processes through value co-creation: a process case from business-to-business service practise", The International Journal of Innovation Management, 22(03).

Nardelli, G, Jensen, J.O and Nielsen, S.B. (2015), "Facilities management innovation in publicprivate collaborations: Danish ESCO projects", Journal of Facilities Management 13(2), 2015.

Nielsen, S.B., Jensen, P.A. and Jensen, J.O. (2012), "The Strategic Facilities Management Organisation in Housing: Implications for Sustainable Facilities Management", International Journal of Facility Management 3(1).

O’Mara, M. (1999), Strategy and Place - Managing Corporate Real Estate and Facilities for Competitive Advantage, The Free Press, New York. 
Osterwalder, A. and Pigneur, Y. (2010). Business model generation: A handbook for visionaries, game changers, and challengers, self-published.

Plane, C.V. and Green, A.N. (2011), "Buyer-supplier collaboration: the aim of FM procurement?", Facilities, 30(3/4), pp. 152-163.

Porter, M.E. (1985), Competitive Advantage - Creating and Sustaining Superior Performance, The Free Press, New York.

Redlein, A. and Zobl, M. (2014), “Outsourcing: a cost-saving approach in FM?”, Proceedings of CIB FM Conference, 21-23 may 2014. Technical University of Denmark.

Rytkönen, E. and Nenonen, S. (2014), Business Model Canvas in University Campus Management, Intelligent Buildings International 6(3), pp. 138-154.

Scupola, A. (2019), ICT in the FM supply chain. Chapter in: Jensen, P.A. (ed.) "Facilities Management Models, Methods and Tools - Research results for practice”. Routledge, Oxfordshire, UK.

Teece, D. (2010), “Business Models, Business Strategy and Innovation”. Long Range Planning 43, pp. 172-194.

Van Meel, J. (2015), Workplaces Today, ICOP and Centre for Facilities Management - Realdania Research, Technical University of Denmark.

Vitasek, K. (2016), “Strategic sourcing business models”, Strategic Outsourcing: an International Journal 9(2), pp. 126-138.

Wiggins, J. (2010), Facilities Manager's Desk Reference, Wiley-Blackwell, Chichester, UK.

Williams, B. (1999), Facilities Economics, Building Economics Bureau Limited, Kent.

Williamson, O.E. (2008), "Outsourcing: transaction cost economics and supply chain management”, 44(2), pp. 5-16. 


\title{
BUSINESS MODELS IN FACILITIES MANAGEMENT VALUE CHAINS
}

\begin{abstract}
$\underline{\text { Abstract }}$
Purpose: To identify typical sourcing strategies and business models in Facilities Management (FM) and map archetypes of value chains with complementary sourcing strategies and value chains.

Methodology: The paper is based on literature and case studies from previous research. Theoretically, the paper takes a generic value chain as a starting point together with the recent ISO standard on sourcing process and a business model framework. A conceptual framework is developed and typical sourcing strategies and business models for FM are investigated. Archetypical values chains are established by a combination of sourcing strategies and business models.
\end{abstract}

Findings: The paper identify 8 archetypes of FM value chains divided in three groups according to whether the core business organisation occupy rented facilities, occupy owned facilities or has facilities operation as a core business like serviced office providers etc.

Implications: The results can be used on a general level by everybody, who need to get an overview and understanding of the complex structure of the FM sector. Furthermore, the results can help all parties involved in the FM value chain to get a clearer understanding of their position in the chain and help them develop their sourcing strategies and/or business model, depending on their type of organisation.

Originality: While there is a huge amount of literature on sourcing in FM, the business models and value chains have only be limited researched. The paper is original in combining an investigation of sourcing strategies, business models and value chains in FM.

Keywords: Facilities Management, value chain, sourcing strategies, business models, maturity, archetypes

\section{Paper type: Conceptual}

\section{Introduction}

During the last decades, the interest infor business models has become evident in business management literature and research into business models has also become important. A main reason for this interest has been the introduction of the internet and other ICT technologies, which have created the possibility to develop many new types of business models, including new disruptive innovations and related business model.

However, within the field of Facilities Management (FM) there has been very little research on business models. One example is a study of business models in connection to university campus management in Finland (Rytkönen and Nenonen, 2014). Another example is a study of business model innovation in a Danish biotech company (Nardelli, 2018xx). Business models are closely 
related to value creation and-value chains, and this is another topic, where there only has been limited research within FM.

On the other side, sourcing has had much attention in FM research, particularly concerning outsourcing and decisions about what services to provide in-house and what services to provide by external companies_(i.e. Ikediashi et al, 2014; Lok and Baldry, 2015; Plane and Green, 2011; Redlein and Zobl, 2014). This obviously have to do with FM being a demand driven sectorfield, where the client og in-house FM organisation via their sourcing strategies set the conditions for external providers - even though the external providers by their marketing activities try to influence the decisions. In that way, sourcing strategies, business models and value chains are closely connected in FM.

The term 'FM sector' is used in the paper, as FM is not just an industry branch consisting of a conglomeration of companies within the same field. The FM sector is centred on specific work activities in companies in combination with markets and service providers and a superstructure with professional bodies and academic institutions (Andersen et al., 2014).

The question in focus of this paper is how sourcing strategies, business models and value chains are connected and what are the typical combinations of these three interrelated elements. Thus, the purpose is to identify typical sourcing strategies and business models in Facilities Management (FM) and map archetypes of value chains with complementary sourcing strategies and value chains in FM.

The term 'FM sector' is used in the paper, as FM is not just an industry branch consisting of a conglomeration of companies within the same field. The FM sector is centred around specific work activities and a profession in combination with markets and companies and a superstructure with professional and trade associations, education and an academic discipline (Jensen and DannemandAndersen, 2010).

The paper is conceptual and draws on literature reviews and a number of case studies from previous research with a combination of the author's own research from the Nordic countries in Europe and case studies from various European countries presented in literature by other authors (i.e. Coenen and Nwanna, 2014; Katchamart, 2013a; Nardelli and Broumels, 2018). Therefore, the paper does not include a separate methods section. The reviewed literature is a combination of sources from $\underline{\text { the author's earlier research on FM, including sourcing strategies and business model, as well as }}$ reviews of the general literature on value chains conducted as part of an ongoing research project concerning business models in relation to sustainable building renovation and the construction value chain (Berg et al., 2019).

The paper reviews theory on value chains, sourcing strategies and business modelsthe mentioned three elements in section 2 , which results in a conceptual model to be used in the further analysis. Section 3 presents tThe paper is oneptual and draws on amber of sulies from previous

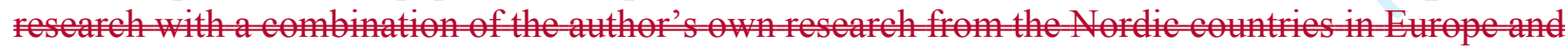
eas sulies from various Europen countries presented in literatme by other authors.Therefore, he paper me mether of analysis is presented together with analysis and findings-in section 3. The paper is-finishes $\mathrm{A}$ with discussion in section 4 and conclusion in section 5 . 


\section{Theory and conceptual framework}

\subsection{Value chains}

The concept of value chain has been important in business management since Michael Porter introduced a generic value chain in his seminalvery influential book on Competitive Advantage (Porter, 1985). Porter's value chain focused on the activities inside a company, but the concept has later been used also for chains of different companies, where output from one part of the chain functions as input tofor the next part with the customer as the final part. A closely related term is supply chain (Nelson, 2004), but in this paper, the term value chain is used.

Porter's generic value chain does not specifically address FM, but it does distinguish between primary activities and support activities, where the primary activities are directly involved in creating value for the external customers, while the secondary activities creates value internally. Thus, both primary and support activities are necessary elements in creating value. FM usually is seen as a support activity.

Jensen (2011a) made an analysis of the relation between FM and core business in a Danish broadcasting corporation, which had applied Porter's generic model to define their value chain. The analysis found that besides the horizontal value chain of the core business, a separate related vertical FM value chain could be identified, which supported all the other internal parts in the value chain.

Jensen and-Scupola (2019 $\theta$ ) analysed the FM value chain in a study of the use of IT in FM. This resulted in the value chain model shown in Figure 1, which distinguish between the basic horizontal FM value chain with external providers, that deliver facilities service to in-house FM, who supports and core business atnd the top and ICT-suppliers and consultant at the bottom. Suppliers and consultantsthat can deliverer IT-solution and consultancy services to all parts in the basic FM value chain. Different suppliers and consulting companies may deliver to each part in the basic value chain, so they are shown for each part as a vertical value chain at the bottom. The basic horizontal FM value chain at the top in Figure 1 will $\underline{\text { is }}$ be the basis for the analysis in this paper.

Figure 1. The FM Value Chain (Jensen and-Scupola, 2019 xx)

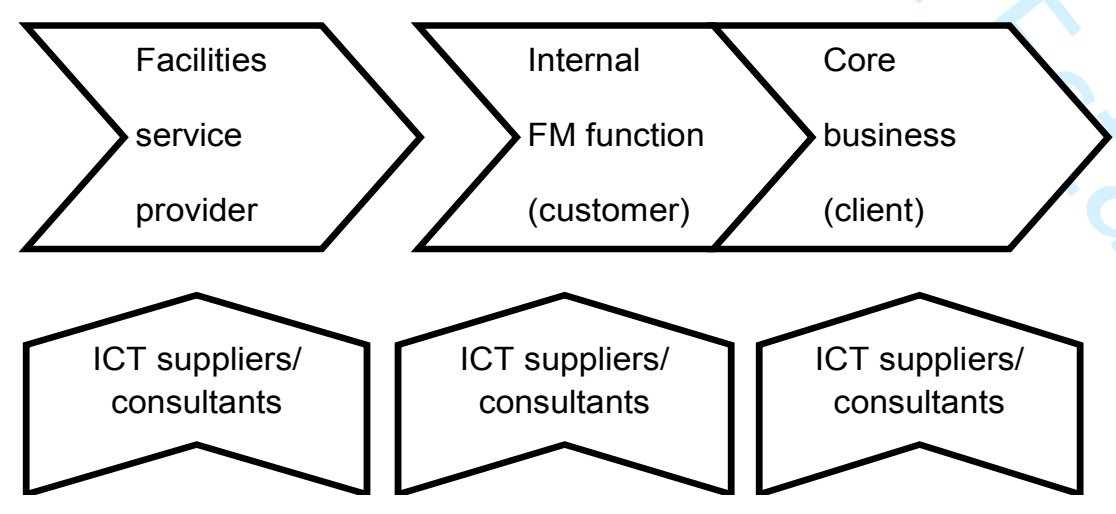




\subsection{Sourcing strategies}

Sourcing is an essential part of FM and much have been written about outsourcing versus in-house provision and different types of outsourcing (i.e. Ikediashi et al, 2014; Lok and Baldry, 2015; Plane and Green, 2011; Redlein and Zobl, 2014). There has even been an international standard published, which includes guidelines for strategic sourcing (ISO, 2016). The standard is structured according to a sequential sourcing model with the following 10 main phases:

1. Sourcing strategy and core business context

2. Identify current and future needs

3. Translate needs into requirements

4. Describe the Service Levels

5. Identify service delivery options

6. Business case development

7. Select preferred sourcing/service delivery option

8. Facilities service provision

- Internal service provision

- External service provision

9. FM service procurement \& FM Agreement

10. Measure service provision performance

Jensen (2017) studied the strategic sourcing process in a Danish case organisation and compared it with the process in the ISO standard. It showed that the process in the case organisation had less phases and more parallel activities in developing the sourcing and procurement strategy. The main problem with the standard is that it is based on the sequential model starting with detailing the demand and needs before investigating sourcing option. The case showed that the ways, needs are specified in tender material depends on the chosen sourcing models. However,Besides that the standard has a sound approach to strategic sourcing being open to combining internal and external service provisions.

Strategic sourcing is theoretically related to the classical corporate management question of making or buying and related to this, coordination based on corporate organisation (hierarchy) or market (Williamson, 2008). The question can be seen as a narrow and short--term economical question of finding the cheapest solution, but it can also be regarded as a strategic issue, where long termlongterm benefits and risks are more in focus. As many organisations have achieved increased experience with outsourcing of FM, the strategic view seems to become more important. Vitasek (2016) investigated 'strategic sourcing business models', but not particularly in relation to FM.

\subsection{Business models}

A business model describes, is a model for what value a business provides to its customers, how it create the value, and how it generate income. There are many definitions of business models. Fielt (2013) analysed many such definitions and concluded, "We define a business model as a representation of the value logic of an organization in terms of how it creates value and captures customer value". Teece (2010) claims that a business model is more generic than a business strategy. However, it is necessary to couple strategy and business model analysis to protect competitive advantage resulting from new business model design. Patenting products and processes can be an effective way to protect business models, but Teece (2010) also points to cospecialisation as a way to create competitive advantages by $ө$ f having key resources and processes developed together over time to create a unique and valuable combinationas a way. 
One of the most widely usedeommon frameworks for analysing and developing business models is the Business Model Canvas (Osterwalder and Pigneur, 2010), which also was used in the earlier mentioned study by Rytkönen and Nenonen (2014). However, the Business Model Canvas includes many different elements and can be complicated to use in research across organisations as experienced by Berg et al. (2017). Therefore,.For this this paper applies the simplerit was decided to use the so-called four blockfour-block framework by Christensen et al. (2016). Theis framework includes Priorities divided in Value proposition and Profit formula and Capabilities divided in Resources and Processes as shown in Table 1. The authors stress that the interrelationships and balance between the four blocks are essential. The value proposition is the first among equals and isean seen as the central dimension of athe business model as stated by Fielt (2013).

Table 1: The Four--Block Business Model Framework (based on Christensen et al., 2016)

\begin{tabular}{|c|c|}
\hline Priorities & Capabilities \\
\hline $\begin{array}{c}\text { Value proposition } \\
\text { A product that helps customers to more } \\
\text { effectively, conveniently, and affordably do a } \\
\text { job they've been trying to do }\end{array}$ & $\begin{array}{c}\text { Resources } \\
\text { People, technology, products, facilities, } \\
\text { equipment, brands, and cash that are required } \\
\text { to deliver this value proposition to the } \\
\text { targeted customers }\end{array}$ \\
\hline $\begin{array}{c}\text { Profit formula } \\
\text { Assets and fixed cost structure, and the } \\
\text { margins and velocity required to cover them }\end{array}$ & $\begin{array}{c}\text { Processes } \\
\text { Ways of working together to address recurrent } \\
\text { tasks in a consistent way: training, } \\
\text { development, manufacturing, budgeting, } \\
\text { planning etc. }\end{array}$ \\
\hline
\end{tabular}

\subsection{Conceptual framework}

In this paper, sourcing strategies and business models are seen as complementary, where sourcing strategies are related to the demand side and business models are related to the supply side. Thus, between each part of the value chain there is a connection to neighbouring parts consisting of a sourcing strategy and one or more business models depending on the sourcing strategyies. This is shown illustrated-in Figure 2, which includes an elaboration of the basic horizontal FM value chain in Figure 1. Cwhere the core business on the right is the ultimate customer, while the chain can be continued to the left with different levels of sub-providers. In this paper, sub-providers will only be addressed as part of the analysis of the other parts.

Figure 2: The FM Value Chain with complementary sourcing strategies and business models

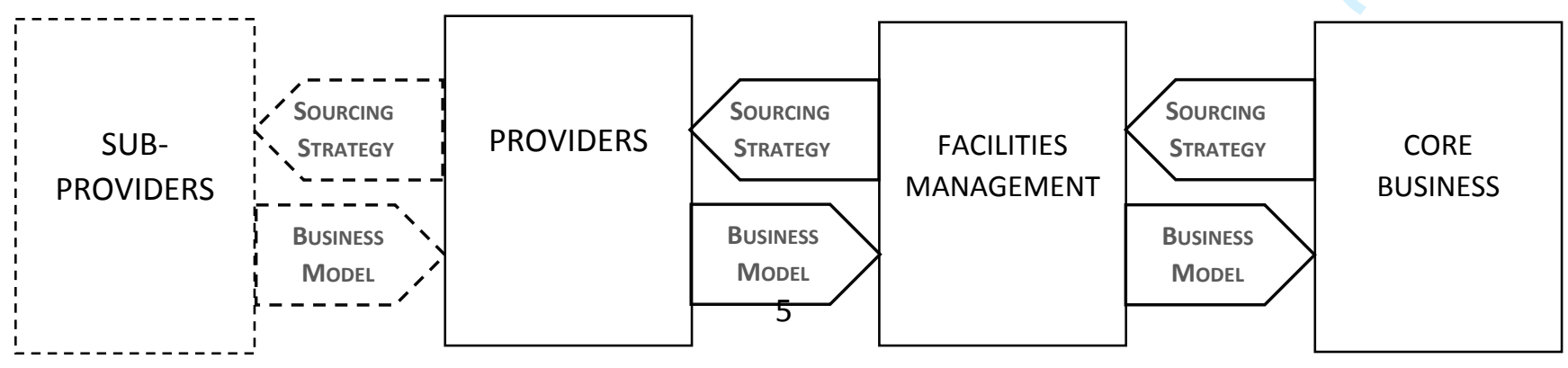




\section{Analysis and findings}

\subsection{Sourcing strategies}

There are a number of different options for sourcing in relation to FM both for the core business and for an in-house FM organisation.

For core business, the basic question is, whether FM should be provided centrally by a special FM organisation or provided de-centrally by each department or business unit. Except for very small businesses, it is has increasingly become mostcommon to establish a special FM organisation. The FM organisation can be in-house with different positions in the corporate structure. It can be an internal staff function, which typically is managed as a cost centre, or it can be a line organisation in which case it possibly can be a profit centre with internal rent and debiting (Kaiser, 1989; Jensen, 2008a). FM can also be part of a shared service centre together with other support function, which is shownthere are in a case studyies of both concerningfrom public organisations in the Netherlands (Katchamart, 2013a)-and a private corporation in Denmark (Jensen and Katchamart, 2012). A solution mainly used by large corporations with subsidiary companies is to establish a subsubsidiary FM company operating on more or less commercial conditions. Two case studies of this are included in Jensen et al. (2008) - one from Denmark and one from Sweden.

Furthermore, there are solutions with integrated space and service provision like serviced offices, incubators and co-working spaces. Jensen et al. (2008) present two case studies of this - an international case of an office hotel company and a case of an incubator at a university in Denmark and V tan Meel (2015) presents three 3 case studies of co-work offices from Amsterdam, Copenhagen and Paris. A special option for public organisations is provision of space and services in new buildings via Public-Private Partnership (Kristiansen, 2019)PPP). Three case studies of PPP are included in Jensen et al. (2008) two from Denmark and one from Iceland.

For in-house FM organisations, the basic question is to which degree services should be provided in-house or by external providers. In most cases the solution will be a combination. The external provision can take place as out-tasking of single services, outsourcing of bundled services or an integrated delivery of most services. The latter solution is sometimes called I-FM (Integrated FM) or T-FM (Total FM), but in this paper it isthis solution will be called I-FS (Integrated Facilities Services). Text and reference books on FM like Jensen (2008a) and Wiggins (2010)The mentioned sourcing solutions are-generally cover the mentioned sourcing solutions.ed by text and reference books on FM, for instance Jensen (2008a) and Wiggins (2010).

There are several other solutions and terms used for sourcing like co-sourcing (partnerships, joint ventures), insourcing and right-sourcing, but the first mentioned are seen as the most important sourcing solutions for in house FM organisations. Partnerships will be addresses in section 4 . Discussion.

\subsection{Business models}

There isare a number of typical business models (BM's) both for in-house FM organisations and for providers. 


\section{BM's for in-house FM (BM-IH)}

For in-house FM, a possible solution is to establish a contract management organisation, which do not provide any operational service, but on the core business (CB) is in charge of managing contracts with one or more external providers - oftentypically an I-FS contract with one provider company. Such a contract management organisation is sometimes called 'the intelligent client' (Williams, 1989; Wiggins, 2010) or the 'informed client' (Atkins and Brooks, 2009).

-To identify other solutions based on developing an in-house FM organisation with some internal service provision, maturity models for FM have been studied as part of this research. Several such maturity models have been developed. In the related field of CREM (Corporate Real Estate Management), Joroff et al. (1993) early on developed a very influential model was developed early en by Joroff et al. (1993). For this paper, the author has mainly-used a combination of two models developed for public FM organisations in Denmark. One One-was developed in connection to establishing a property centre in Copenhagen Municipality and it is described in a case study_by Jensen et al. (2008). The other was developed as part of consultancy report from a management consulting company about generally improving FM in Danish municipalities (EY, 2017). Both maturity models include five levels. Table 2 presents the results of an analysis of the five maturity levels and the contract management solution based on the four block BM framework by Christensen et al. (2016).

\begin{tabular}{|c|c|c|c|c|}
\hline Business model & Value proposition & Profit formula & Resources & Processes \\
\hline $\begin{array}{l}\text { BM-IH1: } \\
\text { Caretaker/ } \\
\text { Limiting cost }\end{array}$ & $\begin{array}{l}\text { Basic offering: } \\
\text { - Basic facilities } \\
\text { services } \\
\text { Additional: } \\
\text { - Minor building } \\
\text { works }\end{array}$ & $\begin{array}{l}\text { Basic offering: } \\
\text { - Budget allocation } \\
\text { (cost centre) } \\
\text { Additional: } \\
\text { - Refund of external } \\
\text { cost of building } \\
\text { work }\end{array}$ & 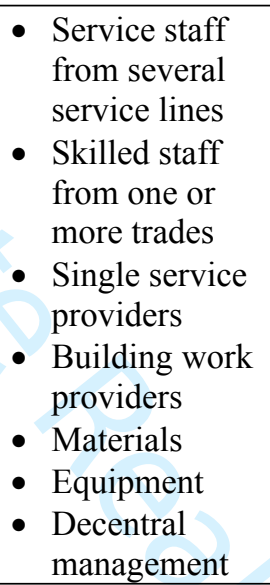 & $\begin{array}{l}\text { - Service operations } \\
\text { and craft based } \\
\text { operations according } \\
\text { to norms and } \\
\text { management } \\
\text { instructions- } \\
\text { - Input and transaction } \\
\text { oriented contracts } \\
\text { with providers- } \\
\text { - Cost focus and no } \\
\text { defined policies- }\end{array}$ \\
\hline $\begin{array}{l}\text { BM-IH2: } \\
\text { Building } \\
\text { owner/ } \\
\text { Operational } \\
\text { efficiency }\end{array}$ & $\begin{array}{l}\text { Basic offering: } \\
\text { - Basic facilities } \\
\text { services } \\
\text { - Basic space } \\
\text { management } \\
\text { Additional: } \\
\text { - Building works }\end{array}$ & $\begin{array}{l}\text { Basic offering: } \\
\text { - Budget allocation } \\
\text { (cost centre) or } \\
\text { income from } \\
\text { internal rent and } \\
\text { debiting (profit } \\
\text { centre) } \\
\text { Additional: } \\
\text { - Refund of external } \\
\text { cost of building } \\
\text { work }\end{array}$ & $\begin{array}{l}\text { As above } \\
\text { exceptplus central } \\
\text { management } \\
\text { plus } \\
\text { - Technicians }\end{array}$ & $\begin{array}{l}\text { As above plus } \\
\text { - Minor planning } \\
\text { activities and } \\
\text { dialogue with client- } \\
\text { - Standardisation of } \\
\text { service levels and } \\
\text { contracts- } \\
\text { - Cost and possibly } \\
\text { also income focus- }\end{array}$ \\
\hline $\begin{array}{l}\text { BM-IH3: } \\
\text { Active building } \\
\text { owner/ } \\
\text { Flexibility }\end{array}$ & $\begin{array}{l}\text { Basic offering: } \\
\text { - Facilities services } \\
\text { - Technical } \\
\text { monitoring } \\
\text { - Space management } \\
\text { Additional: }\end{array}$ & $\begin{array}{l}\text { Basic offering: } \\
\text { - Budget allocation } \\
\text { (cost centre) or } \\
\text { income from } \\
\text { internal rent and }\end{array}$ & $\begin{array}{l}\text { As above plus } \\
\text { - } \text { Bundling of } \\
\text { some services } \\
\text { - } \text { Monitoring } \\
\text { systems } \\
\text { - Consultants } \\
\end{array}$ & $\begin{array}{l}\text { - Service operations } \\
\text { and craft based } \\
\text { operations based on } \\
\text { SLAs with some } \\
\text { output based } \\
\text { contracts- }\end{array}$ \\
\hline
\end{tabular}




\begin{tabular}{|c|c|c|c|c|}
\hline & $\begin{array}{l}\text { - Building works } \\
\text { - Internal consulting }\end{array}$ & $\begin{array}{l}\text { debiting (profit } \\
\text { centre) } \\
\text { Additional: } \\
\text { - Refund of external } \\
\text { cost of building } \\
\text { work }\end{array}$ & & $\begin{array}{l}\text { - Building work based } \\
\text { on project } \\
\text { specifications- } \\
\text { - Technical analyses, } \\
\text { planning, monitoring } \\
\text { with a focus on } \\
\text { optimisation- } \\
\text { - Dialogue with client } \\
\text { and customers- }\end{array}$ \\
\hline $\begin{array}{l}\text { BM-IH4: } \\
\text { Preferred } \\
\text { partner/ } \\
\text { Proactivity }\end{array}$ & $\begin{array}{l}\text { Basic offering: } \\
\text { - Facilities services } \\
\text { - Technical } \\
\text { monitoring } \\
\text { - Space management } \\
\text { - User feedback } \\
\text { Additional: } \\
\text { - Building works } \\
\text { - Internal consulting }\end{array}$ & $\begin{array}{l}\text { Basic offering: } \\
\text { - Income from } \\
\text { internal rent and } \\
\text { debiting (profit } \\
\text { centre) } \\
\text { Additional: } \\
\text { - Refund of external } \\
\text { cost of building } \\
\text { work }\end{array}$ & $\begin{array}{l}\text { As above plus } \\
\text { - Helpdesk }\end{array}$ & $\begin{array}{l}\text { As above plus } \\
\text { - Focus on portfolio } \\
\text { development and } \\
\text { added value- } \\
\text { - Dialogue with client, } \\
\text { customers and end- } \\
\text { users as wells as } \\
\text { collaboration with } \\
\text { other support } \\
\text { functions- } \\
\text { - Perhaps outcome } \\
\text { based contracts. } \\
\end{array}$ \\
\hline $\begin{array}{l}\text { BM-IH5: } \\
\text { Innovator/ } \\
\text { Strategic value } \\
\text { creating }\end{array}$ & $\begin{array}{l}\text { Basic offering: } \\
\text { - Facilities services } \\
\text { - Technical } \\
\text { monitoring } \\
\text { - Space management } \\
\text { - User feedback } \\
\text { Additional: } \\
\text { - Building works } \\
\text { - Internal consulting } \\
\text { - Joint development } \\
\text { projects with CB }\end{array}$ & $\begin{array}{l}\text { Basic offering: } \\
\text { - Income from } \\
\text { internal rent and } \\
\text { debiting (profit } \\
\text { centre) } \\
\text { Additional: } \\
\text { - Refund of external } \\
\text { cost of building } \\
\text { work and } \\
\text { development } \\
\text { projects }\end{array}$ & $\begin{array}{l}\text { As above plus } \\
\text { - Strategic } \\
\text { partnerships } \\
\text { with external } \\
\text { providers. } \\
\text { - R\&D partners }\end{array}$ & $\begin{array}{l}\text { As above plus } \\
\text { - Focus on } \\
\text { development of the } \\
\text { market- } \\
\text { - R\&D projects and } \\
\text { innovation. }\end{array}$ \\
\hline $\begin{array}{l}\text { BM-IH6: } \\
\text { Contract } \\
\text { management }\end{array}$ & $\begin{array}{l}\text { Basic offering: } \\
\text { - Procuring and } \\
\text { controlling a } \\
\text { contract with an I- } \\
\text { FS provider, who } \\
\text { delivers all } \\
\text { facilities services } \\
\text { and related } \\
\text { planning and } \\
\text { management }\end{array}$ & $\begin{array}{l}\text { Basic offering: } \\
\text { - Budget allocation } \\
\text { (cost centre) }\end{array}$ & $\begin{array}{l}\text { - I-FS provider } \\
\text { - Contract } \\
\text { manager } \\
\text { - Supervisors } \\
\text { - Consultants } \\
\text { - Legal advisors }\end{array}$ & $\begin{array}{l}\text { - Governing, } \\
\text { managing and } \\
\text { supervising external } \\
\text { provision } \\
\text { - Dialogue with client } \\
\text { and customers- }\end{array}$ \\
\hline
\end{tabular}

Table 2. Analysis of BM's for in-house FM organisations (BM-IH)

BM-IH1, Caretaker/Limiting cost, is the most basic, where the value proposition is just to sustain the core business with necessary facilities services with no ambitions of improving the core business. Besides the basic facilities services, minor building works can be included in the offering. The profit formula is typically a budget allocation to a cost centre for the basic service and refund of external cost for additional building works. In-house resources mostly include Service staff from several service lines (soft services) and Skilled staff from one or more trades (hard services) and a decentral management, which may not have a special FM qualifications. Besides, the organisation procure external single service providers, building work providers, materials and equipment. The 
processes include service operations and craft based operations according to norms and management instructions. Contracts with providers are typical with transaction oriented input based specifications. Decision--making mostly has cost focus without any defined policies.

BM-IH2, Building owner/Operational efficiency, is also rather basic but-with a similar value proposition, but includewith a stronger focus on space planning. Thus, basic space management is included in the offering. The profit formula can be the same, but it also be based on income from internal rent and debiting (profit centre). Technicians are added to the resources and the processes further include minor planning activities and dialogue with client, standardisation of service levels and contracts. Management of FM is centralised and beside and the beside the focus on cost in decision--making, an income fhocus might be included.

BM-IH3, Active building owner/Flexibility, also has a similar value proposition, but with a stronger focus on professional and technical oriented management. Thus, technical monitoring and possibly internal consulting, is included in the offering. The profit formula is the same as the second $\mathrm{BM}-\mathrm{IH} 2$, but to the resources are added bundling of some services, monitoring systems and use of consultants. The processes included service operations and craft based operations based on Service Level Agreements (SLAs) with some output-based contracts, building work based on project specifications, technical analyses, planning, monitoring with a focus on optimisation and dialogue with client and customers.

BM-IH4, Preferred partner/Proactivity, is characterised by a focus on not just sustaining but also attempts to improve the core business. Thus, responsiveness to user feedback in included in the offering $_{-}=$The basic profit formula is based on income from internal rent and debiting (profit centre). A helpdesk is added to resources and to processes are added a focus on portfolio development and added value, dialogue with client, customers and end-users as wells as collaboration with other support functions and perhaps use of outcome based contracts.

BM-IH5, Innovator/Strategic value creating, has an even stronger focus onand improving the core business and creating joint innovations and development. Thus, joint development projects are added to the additional offering. The profit formula is the same as the fourth-BM-IH4 except for adding possibly refunding of cost of development projects. To resources are added strategic partnerships with external providers and collaboration with R\&D partners and to processes are added focus on development of the market and R\&D projects and innovation.

BM-IH6, Contract management, is fundamentally different bywith a value proposition with the basic offering to procure and control a contract with an I-FS provider, who delivers all facilities services and related planning and management. This can be based on a pure cost focus, but it can also be based on focus on quality and joint development in a strategic partnership, depending on the priority of the core business. The profit formula for contract management is a budget allocation (cost centre) to cover the in-house cost as well astse payments to the I-FS provider and other external cost. The resources are mainly the contractor manager, supervisors and the I-FS provider, but other external partners like consultants and legal advisors could also be involved for specific assignments. The main processes are gGoverning, managing and supervising external provision as well as dialogue with client and customers.

BM's for providers 
For providers it was found appropriate to distinguish between the more general service providers to FM and providers specifically targeting building owners with main focus on building related services - also called 'hard FM'.

The BM's for service providers (BM-SP) more or less mirrors the sourcing options for in-house FM organisations. They include provision of single service, bundled service and I-FS. These are models where services typically are procured by tendering with price competitions. An additional option is management contracting, where a management consultant company takes responsibility for organising the service provision by external providers based on a management fee, incentive based bonus fees and reimbursement of the cost of the service provision. Nardelli and Broumels (2018) did a case study on FM innovation concerning an energy supply company in the Netherlands, which involved a managing contractor. Table 3 presents the results of an analysis of those four business models for service providers and management consultants based on the four block BM framework by Christensen et al. (2016).

\begin{tabular}{|c|c|c|c|c|}
\hline Business model & Value proposition & Profit formula & Resources & Processes \\
\hline $\begin{array}{l}\text { BM-SP1: } \\
\text { Single service }\end{array}$ & $\begin{array}{l}\text { Basic offering: } \\
\text { - Specialised service } \\
\text { delivered regularly } \\
\text { on the client's sites } \\
\text { for a contract } \\
\text { period } \\
\text { Additional: } \\
\text { - Related extra } \\
\text { service on order }\end{array}$ & $\begin{array}{l}\text { Basic offering: } \\
\text { - Fixed price } \\
\text { Additional: } \\
\text { - Hourly rates or } \\
\text { agreed price }\end{array}$ & $\begin{array}{l}\text { - } \text { Specialised } \\
\text { staff from one } \\
\text { service line } \\
\text { - Materials } \\
\text { - Equipment } \\
\text { - } \text { Management }\end{array}$ & $\begin{array}{l}\text { - Standardised service } \\
\text { operations based on } \\
\text { SLA's, norms } \\
\text { and/or management } \\
\text { instructions- }\end{array}$ \\
\hline $\begin{array}{l}\text { BM-SP2: } \\
\text { Bundled } \\
\text { services }\end{array}$ & $\begin{array}{l}\text { Basic offering: } \\
\text { - Two or more } \\
\text { specialised services } \\
\text { delivered regularly } \\
\text { on the client's sites } \\
\text { for a contract } \\
\text { period } \\
\text { - One point of } \\
\text { contact } \\
\text { Additional: } \\
\text { - Related extra } \\
\text { service on order }\end{array}$ & $\begin{array}{l}\text { Basic offering: } \\
\text { - Fixed price } \\
\text { Additional: } \\
\text { - Hourly rates or } \\
\text { agreed price }\end{array}$ & $\begin{array}{l}\text { - Specialised } \\
\text { staff from two } \\
\text { or more service } \\
\text { lines } \\
\text { - Materials } \\
\text { - Equipment } \\
\text { - Management }\end{array}$ & $\begin{array}{l}\text { As above plus } \\
\text { - Coordination of } \\
\text { service provision }\end{array}$ \\
\hline $\begin{array}{l}\text { BM-SP3: } \\
\text { I-FS }\end{array}$ & $\begin{array}{l}\text { Basic offering: } \\
\text { - Several specialised } \\
\text { services delivered } \\
\text { regularly on the } \\
\text { client's sites for a } \\
\text { contract period } \\
\text { - One point of } \\
\text { contact } \\
\text { - Annual cost } \\
\text { reductions } \\
\text { - Improvement } \\
\text { proposals } \\
\text { Additional: } \\
\text { - Related extra } \\
\text { service on order }\end{array}$ & $\begin{array}{l}\text { Basic offering: } \\
\text { - Fixed price with } \\
\text { annual adjustment } \\
\text { - Bonus incentives } \\
\text { and gain sharing } \\
\text { Additional: } \\
\text { - Hourly rates or } \\
\text { agreed price } \\
\text { - Claims from } \\
\text { deficiencies in } \\
\text { contract } \\
\text { specifications }\end{array}$ & $\begin{array}{l}\text { - Specialised } \\
\text { staff from } \\
\text { several service } \\
\text { lines } \\
\text { - Technicians } \\
\text { - Sub-providers } \\
\text { - Materials } \\
\text { - Equipment } \\
\text { - Management }\end{array}$ & $\begin{array}{l}\text { As above plus } \\
\text { - Ongoing reporting, } \\
\text { governance, } \\
\text { improvements and } \\
\text { consulting }\end{array}$ \\
\hline
\end{tabular}




\begin{tabular}{|c|c|c|c|c|}
\hline $\begin{array}{l}\text { BM-SP4: } \\
\text { Management } \\
\text { contracting }\end{array}$ & $\begin{array}{l}\text { Basic offering: } \\
\text { - Responsibility for } \\
\text { several specialised } \\
\text { services delivered } \\
\text { regularly on the } \\
\text { client's sites for a } \\
\text { contract period } \\
\text { - One point of } \\
\text { contact } \\
\text { - Annual cost } \\
\text { reductions } \\
\text { - Improvement } \\
\text { proposals } \\
\text { Additional: } \\
\text { - Related extra } \\
\text { service on order }\end{array}$ & $\begin{array}{l}\text { Basic offering: } \\
\text { - Fixed management } \\
\text { fee } \\
\text { - Bonus incentives } \\
\text { - Direct cost for } \\
\text { service provision is } \\
\text { refunded } \\
\text { Additional: } \\
\text { - Direct cost for extra } \\
\text { service is refunded } \\
\text { - Hourly rates or } \\
\text { agreed price for } \\
\text { additional } \\
\text { management tasks }\end{array}$ & $\begin{array}{ll}\text { - } & \text { Management } \\
\text { consultants } \\
\text { - Supervisors } \\
\text { - Technicians } \\
\text { - Providers } \\
\text { - Management }\end{array}$ & $\begin{array}{l}\text { - Management of } \\
\text { standardised service } \\
\text { operations based on } \\
\text { SLA's } \\
\text { - Ongoing reporting, } \\
\text { governance, } \\
\text { improvements and } \\
\text { consulting }\end{array}$ \\
\hline
\end{tabular}

Table 3. Analysis of BM's for service providers to in-house FM organisations (BM-PS)

BM-SP1, Single service, involves a value proposition with a basic offering of specialised service delivered regularly on the client's sites for a contract period with the additional possibility of related extra service on order. The profit formula is typically based on a fixed price for the basic offering and payment according to hourly rates or agreed price for extra service. $\underline{R}$ The resources are specialised staff from one service line, materials equipment and management. $\mathrm{P}$-and the processes are mostly standardised service operations based on SLA's, norms and /or management instructions.

BM-SP2, Bundled services, resembles BM-SP1, but the value proposition is with a basic offering of two or more specialised services - instead of just one - delivered regularly on the client's sites for a contract period and with one point of contact. The profit formula is the same. Resources also include specialised staff from two or more service lines instead of just from one. To processes is added coordination of service provision.

BM-SP3, I-FS, is more complex. The value proposition includes several specialised services delivered regularly on the client's sites for a contract period with one point of contact, annual cost reductions and improvement proposals and as for the former BM-SP's, additionally extra service on order. The profit formula includes fixed price with annual adjustment related towith bonus incentives and gain sharing as well as additionally payment of extra service according to hourly rates or agreed price and as a new and in some cases important aspect; claims from deficiencies in contract specifications. Resources include specialised staff from several service lines, technicians, sub-providers, materials, equipment and management. The processes include the same as BM-SP2 with addition of ongoing reporting, governance, improvements and consulting.

BM-SP4, Management contracting, is in principle very different in the value proposition and profit formula, but in other waysways, it resembles I-FS with an integrated delivery. The basic offering includes responsibility for several specialised services delivered regularly on the client's sites for a contract period, one point of contact, annual cost reductions and improvement proposals and additionally extra service on order. The profit formula includes fixed management fee, bonus incentives and refunding direct cost for service provision and additionally refunding of direct cost for extra service provision and payment for additional management tasks according to hourly rates 
or agreed price. Resources include management consultants, supervisors, technicians, providers and management. Pand processes include management of standardised service operations based on SLA's and ongoing reporting, governance, improvements and consulting.

The BM's for providers targeting building owners (BM-BO) arewere divided in providers of building work like maintenance, real estate administrations and ESCO (Energy Service Companies). Table 4 presents the results of an analysis of those three BM's. based on the four block business model framework by Christensen et al. (2016).

\begin{tabular}{|c|c|c|c|c|}
\hline Business model & Value proposition & Profit formula & Resources & Processes \\
\hline $\begin{array}{l}\text { BM-BO1: } \\
\text { Building work }\end{array}$ & $\begin{array}{l}\text { Basic offering: } \\
\text { - Specialised services } \\
\text { delivered on a } \\
\text { project basis at the } \\
\text { client's sites } \\
\text { Additional: } \\
\text { - Related extra } \\
\text { service on order }\end{array}$ & $\begin{array}{l}\text { Basic offering: } \\
\text { - Fixed price } \\
\text { Additional: } \\
\text { - Hourly rates or } \\
\text { agreed price } \\
\text { - Claims from } \\
\text { deficiencies in } \\
\text { project } \\
\text { specifications }\end{array}$ & $\begin{array}{l}\text { - Skilled staff } \\
\text { from one or } \\
\text { more trades } \\
\text { - Technicians } \\
\text { - Materials } \\
\text { - Equipment } \\
\text { - Management }\end{array}$ & $\begin{array}{l}\text { - Craft based } \\
\text { operations according } \\
\text { to project } \\
\text { specifications }\end{array}$ \\
\hline $\begin{array}{l}\text { BM-BO2: } \\
\text { Real estate } \\
\text { administration }\end{array}$ & $\begin{array}{l}\text { Basic offering: } \\
\text { - Rent out space for } \\
\text { building owners } \\
\text { and collect rent } \\
\text { from tenants } \\
\text { Additional: } \\
\text { - Operation and } \\
\text { maintenance } \\
\text { - Rebuilding and } \\
\text { refurbishment } \\
\text { - Real estate } \\
\text { development } \\
\text { - Consultancy }\end{array}$ & $\begin{array}{l}\text { Basic offering: } \\
\text { - Fee as a fixed } \\
\text { percentage of rent } \\
\text { income for rent } \\
\text { administration } \\
\text { Additional: } \\
\text { - Fee as a fixed } \\
\text { percentage of rent } \\
\text { income for } \\
\text { operation and } \\
\text { maintenance } \\
\text { - Hourly rates or } \\
\text { agreed price for } \\
\text { projects and } \\
\text { consultancy }\end{array}$ & $\begin{array}{l}\text { - Economist } \\
\text { - Lawyers } \\
\text { - Technicians } \\
\text { - Caretakers and } \\
\text { - Service staff } \\
\text { - Supervisors } \\
\text { - Sub-providers } \\
\text { - Management }\end{array}$ & $\begin{array}{l}\text { - Administrative } \\
\text { processes; possibly } \\
\text { supplemented with: } \\
\text { - Service operations } \\
\text { - Craft based } \\
\text { operations, } \\
\text { - Project management } \\
\text { - Consulting }\end{array}$ \\
\hline $\begin{array}{l}\text { BM-BO3: } \\
\text { ESCO }\end{array}$ & $\begin{array}{l}\text { Basic offering: } \\
\text { - Energy savings in a } \\
\text { portfolio of } \\
\text { buildings for the } \\
\text { building owner } \\
\text { Additional: } \\
\text { - Instruction of in- } \\
\text { house FM staff }\end{array}$ & $\begin{array}{l}\text { Basic offering: } \\
\text { - Fee based on } \\
\text { guaranteed energy } \\
\text { savings } \\
\text { Additional: } \\
\text { - Gain sharing from } \\
\text { additional savings } \\
\text { - Claims from } \\
\text { changes in baseline }\end{array}$ & $\begin{array}{l}\text { - } \text { Technicians } \\
\text { - Skilled staff } \\
\text { from different } \\
\text { trades } \\
\text { - Monitoring } \\
\text { - } \text { systems } \\
\text { - Management }\end{array}$ & $\begin{array}{l}\text { - Craft based } \\
\text { operations and } \\
\text { technical analyses, } \\
\text { planning and } \\
\text { monitoring }\end{array}$ \\
\hline
\end{tabular}

Table 4. Analysis of BM's for providers targeting building owners (BM-BO)

BM-BO1, Building work, is characterised by a value proposition of specialised services delivered on a project basis at the client's sites and additionally extra service on order. The profit formula is as simple as fixed price often based on competitive tendering and additionally payment for extra service according to hourly rates or agreed price and as for BM-PS3 (I-IFS); claims from deficiencies in project specifications. Resources include skilled staff from one or more trades, 
technicians, materials, equipment and management and processes include craft based operations according to project specifications.

$\mathrm{BM}-\mathrm{BO} 2$, Real estate administration, is characterised by a value proposition of renting out space for building owners and collecting rent from tenants and additionally operation and maintenance, rebuilding and refurbishment, real estate development and consultancy. The profit formula is fee as a fixed percentage of rent income for rent administration and additionally fee as a fixed percentage of rent income for operation and maintenance payment according to hourly rates or agreed price for projects and consultancy. Resources include economist, lawyers, technicians, caretakers/service staff, supervisors, sub-providers and management. Processes includes administrative processes; possibly supplemented with service operations, craft based operations, project management and consulting.

$\mathrm{BM}-\mathrm{BO} 3, \mathrm{ESCO}$, represents a ratherquite unique BM. The value proposition is energy savings in a portfolio of buildings for the building owner and additionally instruction of in-house FM staff, while the profit formula is fee based on guaranteed energy savings and additionally gain sharing from additional savings and claims from changes in baseline. The resources include technicians, skilled staff from different trades, monitoring systems and management and the processes are craft based operations and technical analyses, planning and monitoring.

\subsection{Archetypes of FM value chains}

The FM value chain consists as described in section 2.1 of core business as the customer, which is supported by an internal FM organisation responsible for service provision; possibly with a combination of in-house provision and provision from external providers, who also can have subproviders. From the analysise it was found that FM value chains could be grouped according to the type of facilities and ownership of facilities that the core business occupy. It was found appropriate to group the value chains according to core businesses in rented facilities, own (owned) facilities and facilities operated to be used by other companies like serviced offices etc.

The distinction between rented and own facilities is not related to the formal financial arrangement but to who has the owner responsibility; particularly in relation to building maintenance and operation of the shell and basic technical infrastructure and for multi-user property also of shared facilities outdoor and indoor. Rented and own facilities are both typically related to situations, where staff in the company and possibly visitors are the end users.

Facility operators are seen as organisations, who have FM as integrated part of their core business. Here the end users typically are staff from customer companies for the operator or individual customers. For instance, shopping centre management companies are responsible for operating shopping centres and their direct customers are the shops, who rent space at the shopping centre, but the public using the shopping centre are customers for the shops. Thus, the public using the shops are customer's customers for the shopping centre management company, and their shopping experience is essential for the whole shopping centre as explained in a; see case study of a Danish shopping centre management company (in-Jensen et al., (2008).

A similar situation characterizes airports, where the direct customers for the airport operator are the airlines and the shops in the airport, while the passengers are customers for the airlines and shops. Thus, the passengers are customer's customers for the airport operator, and their experience of visiting the airport is just as important for the whole airport as it is for the whole shopping centre; see case study of Copenhagen Airport in Jensen et al. (2008). 
The formal ownership is not important in this context for shopping centres and airports-and many other types of facilities operators, but when it comes to management of housing estate, ownership has a fundamental importance. According to an analysis by Nielsen et al. (2012 $\approx$ ) of the so-called strategic FM organisation in housing organizations under different types of ownership, a difference between a strong demand driven strategic management in social and cooperative housing associations and an increasingly stronger supply driven management in privately owned housing companies could be identified.

Small companies will typical choose between one of the three groups for their facilities solution. Large corporations may have a combination of occupying facilities from all three groups but in that ease, they utilise a combination of value chains. Production companies often own their headquarters and production facilities, but they may rent additional offices and storage space as well as serviced office spaces in different locations.

Table 5 presents an overview of eight archetypes of FM value chains divided in the three groups with the modification that the first group both can be relevant for rented and own facilities. For practical reasons, the value chains are shown in the opposite order than in Figure 1 and 2 starting with core business in the secondfirst column from left.

\begin{tabular}{|c|c|c|c|c|}
\hline$\frac{\text { FM value }}{\text { chain }}$ & Core business & FM & Providers & Sub-providers \\
\hline FM-VC1 & \multirow[t]{2}{*}{$\begin{array}{l}\text { Rented facilities or } \\
\text { Own facilities }\end{array}$} & $\begin{array}{l}\text { Caretaker/ } \\
\text { Limiting cost }\end{array}$ & Single service & \\
\hline FM-VC2 & & Contract manager & $\begin{array}{l}\text { Single } \\
\text { Bundled services } \\
\text { I-FS }\end{array}$ & Single service \\
\hline FM-VC3 & \multirow[t]{4}{*}{ Own facilities } & $\begin{array}{l}\text { Building owner/ } \\
\text { Operational efficiency }\end{array}$ & $\begin{array}{l}\text { Single service } \\
\text { Bundled services } \\
\text { Building work }\end{array}$ & \\
\hline FM-VC4 & & $\begin{array}{l}\text { Active building owner/ } \\
\text { Flexibility }\end{array}$ & $\begin{array}{l}\text { As above plus } \\
\text { Consultants } \\
\text { Legal advisors } \\
\text { ESCO }\end{array}$ & \\
\hline FM-VC5 & & $\begin{array}{l}\text { Preferred partner/ } \\
\text { Proactivity }\end{array}$ & $\begin{array}{l}\text { As above } \text { or } \\
\text { I-FS or } \\
\text { Management } \\
\text { contractor }\end{array}$ & $\begin{array}{l}\text { If I-FS or Management } \\
\text { contractor: } \\
\text { Single service } \\
\text { Building work } \\
\text { Consultants } \\
\text { Legal advisors }\end{array}$ \\
\hline FM-VC6 & & $\begin{array}{l}\text { Innovator/ } \\
\text { Strategic value creating }\end{array}$ & $\begin{array}{l}\text { As above } p l u s \\
\text { R\&D partners }\end{array}$ & As above \\
\hline FM-VC7 & \multirow{2}{*}{\multicolumn{2}{|c|}{$\begin{array}{l}\text { Facilities operator } \\
\text { (serviced office providers, shopping centre, } \\
\text { airports, culture houses, housing associations, } \\
\text { PPPs etc.) }\end{array}$}} & $\begin{array}{l}\text { Real estate } \\
\text { administration }\end{array}$ & $\begin{array}{l}\text { Single service } \\
\text { Bundled service } \\
\text { Building work } \\
\text { Consultants }\end{array}$ \\
\hline FM-VC8 & & & $\begin{array}{l}\text { Single service } \\
\text { Bundled service } \\
\text { Building work } \\
\text { Consultants } \\
\text { Legal advisors } \\
\text { ESCO }\end{array}$ & \\
\hline
\end{tabular}


Table 5. Typical FM value chains

Two value chains are the same for rented and own facilities. FM-VC1 includes an in-house FM organisation with focus on Cearetaking/L_and limiting cost (BM-IH1) with-possiblye withinvolvement of single service providers. FM-VC2 includes an in-house Ceontract Mmanager (BM-IH6), who engage single and/or bundled service providers. FM-VC1 and FM-VC2 are placed together and can both be seen as being on the lowest level of maturity with of focus on 'no frills' FM product as Katchamart (2013 $\underline{b}$ ) call the lowest level of complexity in his characterisation of FM products. However, contract management can be on a high level of sophistication particularly with I-FS solutions and thereby equivalent to one of the higher maturity levels for in-house FM organisations.

Besides FM-VC1 and FM-VC2, there are four value chains specifically for own facilities and they reflect the maturity models, which formed the main basis for Table 2. FM-VC3 is related to Building owner/Operational efficiency (BM-IH2), which might engage single service, bundled service and/or building work providers. FM-VC4 is related to Active building owner/Flexibility, which additionally might engage consultants, legal advisors and/or ESCO. FM-VC5 is related to Preferred partner/Proactivity, which might engage the same as FM-VC4 or an I-FS provider or a management contractor as well as various sub-providers. FM-VC6 is related to Innovator/Strategic value creating, which might engage R\&D partners in addition to those for FM-VC5.

Facilities operators are characterised by both-representing both core business and FM as FM is an integrated part of the core business. There are two value chains for facilities operators. FM-VC7 involves engaging a real estate administration, which might engage single service, bundled service and/or building worker sub-providers and/or consultants. FM-VC8 involves the facility operator directly engaging single service, bundled service and/or building work providers and possibly consultants, legal advisors and/or ESCO.

\section{Discussion}

\section{Origin of the different sourcing strategies and business models}

Contract management has existed for centuries and was developed to some sophistication during the Roman Empire as shown by Bröchner (2010). Caretaking probably has even longer historical roots and was in earlier historical times often undertaken by slaves.

In modern times, out-tasking with single services initially was the dominant solution of external provision and often procured by negotiation without detailed requirement specifications and competitive tendering. An example is the cleaning contract between the Danish Broadcasting Corporation (DR) and ISS in the early 1990'ies had 50 years anniversary without ever having been in a competition. That possibility was abandoned byehange with introduction of EU's procurement legislation for public clients and DR soon after had all cleaning service out for EU tendering resulting in drastic cost reductions as well asnd alse initially problems to obtain the required quality (Jensen, 2008b). Outsourcing with bundled services is relatively new phenomenon and has $v e$ gradually developed as an extension of out-tasking/single services since the 1990's. 
Managing contracts were introduced in the Nordic countries in 1995 by IBM's pan-European FM contract with Johnson Controls (Jensen, 2008a). This was followed in Sweden by the establishing of Skanska FM (now Coor Service Management) as a management consulting company in 1998, and they for instance started a long lasting collaboration with the Swedish telecommunication company L.M. Ericsson in 2000. The threat of being reduced to a sub-provider for management consultants resulted in ISS changing its strategy in 2000 from being a cleaning company towards becoming an I-FS provider. Case studies of these developments are included in Jensen et al. (2008).

For property investors, the collaboration with real estate administrations goes a long way back. Serviced offices and incubators mostly started after year 2000 and was later followed by coworking spaces.

Public-Private Partnerships were started in the UK by political decision in the 1980's during Margaret Thatcher's government. Iceland became the frontrunner for PPP in the Nordic country until it collapsed during the financial crisis from 2008. In Denmark, PPP was introduced after year 2000 on government initiative and the first project was a school building in Jutland starting in 2004 (Jensen et al., 2008). ESCO has a long history in some countries like Sweden and USA (Jensen et al., 2008), but ESCO was introduced in Denmark around 2008, when it started to be used by a number of municipalities (Nardelli et al., 2015).

\section{Frends in the development}

The general trend towards increased use of external providers (outsourcing in a broad sense) is ongoing even though slowly in the most mature markets in Northern Europe, while there is a fast growth, for instance in parts of Asia. Market surveys for The Netherlands, which is one of the most mature markets, showed the growth continued during the financial crisis from 63 percent in 2009 to 64 percent in 2011 even though the total market volume slightly decreased in the same period (Van der Spil, 2013).

The Swedish branch of the management consulting company Capgemini made a study of the Nodic FM market, which concluded that the Nordic countries are leading the trend towards IFS and expected that I FS would have a higher growth rates than other parts of the outsourcing market Eapgemini (2005). At least in Denmark, it seems that managing contracts have been replaced by IFS on comprehensive contracts, and managing contracts are mainly used in catering, where quality and user satisfaction often I given higher priority than lowest price, because catering is seen as a fringe benefit of importance to attract and attain staff.

In recent years, there has been an increased focus on more partnership based I FS contract with focus on outcome specification with user satisfaction as a main KPI, which in some cases is used to determine the remuneration of the I-FS provider. A case study from the mobile communication company Sony Eriesson is included in Jensen and der Voordt (2017). An American author has developed as special version of outcome based contract calle Vested Outsourcing (Vitasek, 2016). Other studies have showed that increased global coordination of FM in multinational companies has developed and that multinational companies increasingly make use of global FM providers (Jensen, 2013; Katchamart, 2013; Van der Kluit, 2005).

The development in Denmark has shown that the uptake of PPP has been limited in spite of strong political interest from central government (Kristiansen, 2019). ESCO has had a fast development 
in Danish municipalities since the start in 2008, but the interest among municipalities has been reduced again, but ESCO is increasingly used in other sectors like hospitals, housing and industry. Serviced offices and co-working are becoming more and more widespread and this is probably a global trend. Van Meel (2015) writes that the first co-work space to style itself as such started in San Francisco in 1995 and he cites a survey from 2010 stating co-working mostly was a hipster phenomenon. He also refers to another survey from 2013 estimating that there were about 2,500 co-work spaces across the world with approx. 110,000 members. Van Meel found these number quite impressive for such a young phenomenon and expected the concept will become more mainstream in the coming years.

\section{The characteristics of business models in the FM sector}

The presented business models are regarded as representing the most important types. Individual organisations will belong to one type, but their specific business model will have more details and not least, the capabilities and the relationships between the building blocks must have special characteristics for the company to create unique features and competitive advantage as pointed out by Teece (2010). However, the FM sector is a demand based sectorfield of business. Thus, the demand side needs to set sourcing conditions for their providers, so that there is a sufficient number of provider companies that can comply with them. Similarly, the supply side needs to have business models that are general enough to be attractive to a sufficient number of different clients. This limits how unique the business models for FM providers can be.

Christensen et al. (2016) developed a life cycle model with three stages of business model's journey. It resembles the well-known product life cycle. They claim that business models over time become more resistant to change. However, this seems to be based on an analysis of supply based companies (like much international business management literature) that pushes products to a market, while for FM as demand based sectorbusiness, client organisations pull service contracts via tendering from providers. Therefore, it could be hypothesized that business models in the FM sector are less tightly knit and more flexible in relation to modifications in accordance towith changes in the market conditions. The FM relationship lifecycle model developed by Coenen and Nwanna (2014) might be more relevant for the FM sector than the mentioned BM life cycle model.

New business models for FM are likely to be developed in the future and particularly new disfuptive technologies and other innovations will probably change part of the industry. There is at the moment high expectations to the potential impact of Internet of Things, censor technology, big date and robotics, but the disruption may come from unexpected sources and in surprising ways. However, one of the characteristics of the FM sector is that most services have to be delivered on the specific sites, where client organisations are located. This sets some restrictions to what new developments are possible, but it also make remote and wireless monitoring and control very powerfut.

\section{Influencing factors}

The variety of value chains in the FM sector is an expression of the high complexity that characterises the sector. The value chains are strongly dependent on the facility solution that the core business make use of, but there are still more than one available value chain for each of the three main facilities solution. There are at least three factors influencing the choice of value chain and some likely influences are suggestedpresented in the following. 
Company size: The larger an organisation is, the more likelihood there is off a more complex value chain or making use of more than one value chain.

Company complexity: The higher the complexity of a business, the more likelihood is over time to develop an FM organisation on a higher maturity level and make use of a more complex value chain. Office based companies will typically have a rather simple value chain ${ }_{2}$ while more complex businesses like production companies, airports, hospitals, universities etc. probably will make use of more complex value chains.

Dynamics of the environment: This can influence in different ways and be related to the generic space strategies identified by O'Mara (1999):

- Companies in a fast changing and uncertain markets, for instance start-ups, IT and consulting companies, are likely to follow an incremental strategy and apply a simple value chain with rented facilities

- Well consolidated companies under secure and expanding market conditions will-are likely to follow a standardisation strategy and make use of a complex value chain

- Companies with a value-based strategy are likely to reconsider their FM value chain to become aligned with the new values, which can have varying consequences depending on the views of the top management.

Space strategies will typically change over time. A case study of the Danish Broadcasting Corporation over its lifetime from 1925 to 2005 showed that the space strategy in average changed every 12 years (Jensen, 2011b). This will probably lead to changes in business model and value chain as well.

\section{Implications}

Firstly, the results be bed on genallevel by understanding the complex stucture of the FM sector and how FM creat value. This includes professional and tras as iations, politicians and public authorities, teachers and researchers, top managers involved in decision-making concening FM and strategists in organisations involved in

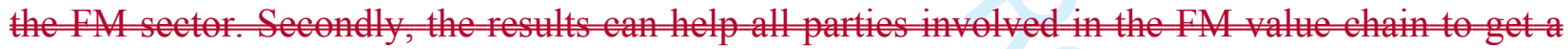
elearer understanding of their position in the hain and help them futher develop their someing

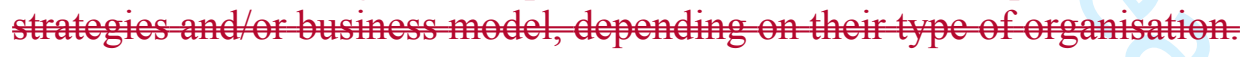

\section{Conclusion}

The purpose of this paper was to identify typical sourcing strategies and business models in Facilities Management (FM) and map archetypes of value chains with complementary sourcing strategies and value chains. The paper identified 8 archetypes of FM value chains divided in three groups according to whether the core business organisation occupy rented facilities, occupy owned facilities or has facilities operation as a core business like serviced office providers etc. While there is a huge amount of literature on sourcing in FM, the business models and value chains have only be limited researched. The novelty of the paper is the combination of investigating of sourcing strategies, business models and value chains in FM. 
TFirstly, the results can be used on a general level by everybody, who needs to get an overview and understanding of the complex structure of the FM sector and how FM create value. This includes professional and trade associations, politicians and public authorities, teachers and researchers, top managers involved in decision-making concerning FM and strategists in organisations involved in the FM sector. TSecondly, the results can also help all parties involved in the FM value chain to get a clearer understanding of their position in the chain and help them further develop their sourcing strategies and/or business model, depending on their type of organisation.

The results can be used on a general level by everybody, who need to get an overview and understanding of the complex structure of the FM sector and how FM create value. Furthermore, the results can help all parties involved in the FM value chain to get a clearer understanding of their position in the chain and help them further develop their sourcing strategies and/or business model, depending on their type of organisation.

The paper is conceptual, based on theory and former-case studies from previous research. The sourcing strategies are well documented, and the business models are at an overall level also well known, but the detailed analysis of the different business models could benefit from validation by other researchers and further empirical foundation. Most of the identified FM value chains much be regarded to have a preliminary character and need substantial validation. Hower, they present a synthesis of the author's experience and knowledge from 15 years as practitioner and 15 years as researcher of FM and is expected to provide a profound basis for further research.

\section{References}

Andersen, P.D., Andersen, A.D., Jensen, P.A. and Rasmussen, B. (2014), "Innovation-system foresight in practice. Nordic facilities management foresight". Futures, 61(September), pp. 33-44.

Atkins and Brooks (2009), Total Facilities Management, Third Edition, Wiley-Blackwell, Chichester, UK.

Berg, B.B., Thuesen, C., Ernstsen, S.K. and Jensen, P.A. (2019), "Constructing Archetypes: Mapping Business Models in the Construction Value Chain". Working paper presented at ARCOM 2019 Conference, Leeds, UK, 2-4 September 2019.

Bröchner (2010), "Innovation and ancient Roman facilities management", Journal of Facilities Management 8(4), 246-255.

Capgemini (2005), More for less A Nordic Facilities Management Study 2004/2005, Capgemini, Stockholm.

Christensen, C.M., Barman, T. and van Bever, D. (2016) "The Hard Thruth about Business Model Innovation”. MIT Sloan Management Review 58(11), pp. 30-30. 
Coenen, C. and Nwanna, P. (2014), "Discovering the Relationship Lifecycle in FM: Phases and Driver of Costumer Value Perceptions", Proceedings of EFMC 2014 Conference and Research Symposium, Berlin, 4-6 June 2014.

EY (2017), Kortloegning af facility_management i kommunerne_.. Ernst \& Young, Denmark.

Fielt, E. (2013), “Conceptualising Business Models: Definitions, Frameworks and Classification”, Journal of Business Models 1(1), pp. 85-105.

Ikediashi, D.I, and Ogunlana, S.O. and Boateng, P. (2014), "Determinants of outsourcing decision for facilities management (FM) services provision”, Facilities, 32(9/10), pp. 472-489.

ISO (2016), Facility Management - Part 2: Guidance on strategic sourcing and the development of agreements, International Standard ISO 41012, International Organization for Standardization.

Jensen, P.A. (2008a) Facilities Management for Practitioners and Students, Centre for Facilities Management - Realdania Research, DTU Management Engineering, Lyngby, Denmark

Jensen, P.A. (2008b), "The Origin and Constitution of Facilities Management as an Integrated Corporate Function", Facilities 26(13/14), pp. 490-500.

Jensen, P.A. (2011a), "Organisation of Facilities Management in relation to Core Business", Journal of Facilities Management 9(2), pp. 78-95.

Jensen, P.A. (2011b), "Strategy and Space: A Longitudinal Case Study of Broadeasting Facilities", International Journal of Strategic Property Management, 15(1), pp. 35-47.

Jensen, P.A. (2012), "International coordination of facilities management in multinational corporations", Proceeding of International Congress on Construction Management Research CIB International MCRP Conference, Montrea1, 26-29 June 2012.

Jensen, P.A. (2017), "Strategic Sourcing and Procurement of Facilities Management Services", Journal of Global Operations and Strategic Sourcing 10(2), pp. 138-158.

Jensen, P.A. and Dannemand-Andersen, P. (2010), Research Report. Centre for Facilities Management Realdania Research, DTU Management Engineering, Report 21.2010, Lyngby, Denmark.

Jensen, P.A. and Katchamart, A. (2012), "Value Adding Management: A Concept and a Case", chapter 10 in Jensen, P.A., van der Voordt, T. and Coenen, C. (eds.): The Added Value of Facilities Management Concepts, Findings and Perspectives, Centre for Facilities Management - Realdania Research, DTU Management Engineering, and Polyteknisk Forlag, Lyngby, Denmark, pp. 164 176.

Jensen, P.A. and Seupola, A. (2010), "ICT Adoption in the Danish Facilities Management Supply Chain: What are the factors that matter?". Construction Matters Conference. Copenhagen 5-7 May 2010 .

Jensen, P.A. and van der Voordt, T. (eds.) (2017), "Facilities Management and Corporate Real Estate Management as Value Drivers: How to Manage and Measure Adding Value", Routledge, Oxfordshire, UK. 
Jensen, P.A., Nielsen, K. and Nielsen, S.B. (2008), Facilities Management Best Practice in the Nordic Countries - 36 cases, Centre for Facilities Management - Realdania Research, DTU Management Engineering.

Joroff, M., Louargard, M., Lambert, S. and Becker, F. (1993), Strategic Management of the Fifth Resource: Corporate Real Estate Management, Industrial Development Research Foundation, USA.

Kaiser, H.H. (1989), Facilities Manager's Reference - Management, Planning, Building Audits, Estimating, R.S. Means Company, INC. Construction Consultants and Publishers, Kingston, MA, USA.

Katchamart, A. (2013a), Profiling Value Added Position in FM, PhD thesis 8.2013, DTU Management Engineering, Lyngby, Denmark.

Katchamart, A. (2013b), "Mapping value added positions in facilities management by using a product-process matrix” Journal of Facilities Management 11(3), pp. 226 - 252.

Kristiansen, K. (2019), Public-Private Partnerships and FM. Chapter in: Jensen, P.A. (ed.) "Facilities Management Models, Methods and Tools - Research results for practice". Routledge, Oxfordshire, UK.

Lok, K.A. and Baldry, D. (2015), "Facilities management outsourcing relationships in the higher education institutes", Facilities, 33(13/14), pp. 819-848.

Nardelli, G, and Rajala, R. (2018), "The evolution of facility management business models in supplier-client relationships" Journal of Facilities Management 16(1), pp. 38-53.

Nardelli, G. and Broumels, M. (2018), "Managing innovation processes through value co-creation: a process case from business-to-business service practise", The International Journal of Innovation Management, 22(03).

Nardelli, G, Jensen, J.O and Nielsen, S.B. (2015), "Facilities management innovation in publicprivate collaborations: Danish ESCO projects", Journal of Facilities Management 13(2), 2015.

Nelson, M.M. (2004), "The Emergence of Supply Chain Management as a Strategic Facilities Management Tool", chapter 7 in Alexander, K., Atkin, B., Bröchner, J. and Haugen, T. (Ed.), Facilities Management Innovation and Performance, Spon Press, London and New York, pp. 83-94.

Nielsen, S.B., Jensen, P.A. and Jensen, J.O. (2012), "The Strategic Facilities Management Organisation in Housing: Implications for Sustainable Facilities Management", International Journal of Facility Management 3(1).

O’Mara, M. (1999), Strategy and Place - Managing Corporate Real Estate and Facilities for Competitive Advantage, The Free Press, New York.

Osterwalder, A. and Pigneur, Y. (2010). Business model generation: A handbook for visionaries, game changers, and challengers, self-published. 
Plane, C.V. and Green, A.N. (2011), "Buyer-supplier collaboration: the aim of FM procurement?", Facilities, 30(3/4), pp. 152-163.

Porter, M.E. (1985), Competitive Advantage - Creating and Sustaining Superior Performance, The Free Press, New York.

Redlein, A. and Zobl, M. (2014), “Outsourcing: a cost-saving approach in FM?", Proceedings of CIB FM Conference, 21-23 may 2014. Technical University of Denmark.

Rytkönen, E. and Nenonen, S. (2014), Business Model Canvas in University Campus Management, Intelligent Buildings International 6(3), pp. 138-154.

Scupola, A. (2019), ICT in the FM supply chain. Chapter in: Jensen, P.A. (ed.) "Facilities Management Models, Methods and Tools - Research results for practice". Routledge, Oxfordshire, $\underline{\mathrm{UK}}$.

Teece, D. (2010), “Business Models, Business Strategy and Innovation”. Long Range Planning 43, pp. 172-194.

Van der Kluit, J. (2005), Managing a Multinational's Facility Management organization across borders, Master Thesis. Wageningen University. August 2005.

Van der Spil, T. (2013) "Facilities market contracts again survey of the Dutch FM market published", European FM Insight, EuroFM, Nareden, pp. 56.

Van Meel, J. (2015), Workplaces Today, ICOP and Centre for Facilities Management - Realdania Research, Technical University of Denmark.

Vitasek, K. (2016), “Strategic sourcing business models", Strategic Outsourcing: an International Journal 9(2), pp. 126-138.

Wiggins, J. (2010), Facilities Manager's Desk Reference, Wiley-Blackwell, Chichester, UK.

Williams, B. (1999), Facilities Economics, Building Economics Bureau Limited, Kent.

Williamson, O.E. (2008), "Outsourcing: transaction cost economics and supply chain management”, 44(2), pp. 5-16. 


\section{Response to editor and reviewers' comments}

Thanks to the editor and reviewers for the constructive comments. Please find my response in the tables below.

\begin{tabular}{|l|l|}
\hline Editor's comments & Response \\
\hline $\begin{array}{l}\text { Please shorten the paper to fit within the } \\
8,000 \text { word limit of the journal }\end{array}$ & $\begin{array}{l}\text { The paper has been reduced and is now below } \\
\text { the } 8.000 \text { word limit. Particularly the } \\
\text { discussion section has been shortened and the } \\
\text { sub-section on Trends in the development has } \\
\text { been completely skipped. }\end{array}$ \\
\hline $\begin{array}{l}\text { The reviewers both mention that your paper } \\
\text { heavily leans on references to your own } \\
\text { previous works. So, I invite you to respond to } \\
\text { the reviewer(s)' comments and revise your } \\
\text { manuscript, but also especially want to } \\
\text { challenge you to include discussion of other } \\
\text { authors and try to limit self-referencing where } \\
\text { other works exist as well. }\end{array}$ & $\begin{array}{l}\text { With the revision and shortening of the paper, } \\
\text { freferences has been removed, including 6 } \\
\text { from my own previous research, while 9 new } \\
\text { references have been added. }\end{array}$ \\
\hline
\end{tabular}

\begin{tabular}{|l|l|}
\hline Reviewer 1 & Response \\
\hline $\begin{array}{l}\text { The development of the paper is good and the } \\
\text { discussion of business models in FM is }\end{array}$ & $\begin{array}{l}\text { The introduction section now includes the } \\
\text { following paragraph: } \\
\text { relevant. I think you need to include a } \\
\text { methodology on how you accessed your }\end{array}$ \\
$\begin{array}{l}\text { literature as the paper is highly dependent on } \\
\text { this and also further discuss the different } \\
\text { cases you use. }\end{array}$ & $\begin{array}{l}\text { literature reviews and a number of case studies } \\
\text { from previous research with a combination of } \\
\text { the author's own research from the Nordic } \\
\text { countries in Europe and case studies from } \\
\text { various European countries presented in } \\
\text { literature by other authors. Therefore, the } \\
\text { paper does not include a separate methods } \\
\text { section. The reviewed literature is a } \\
\text { combination of sources from the author's } \\
\text { earlier research on FM, including sourcing } \\
\text { strategies and value chains, as well as reviews } \\
\text { of the general literature on business models } \\
\text { conducted as part of an ongoing research } \\
\text { project concerning business models in relation } \\
\text { to sustainable building renovation and the } \\
\text { construction value chain (Berg et al., 2019)." }\end{array}$ \\
\hline $\begin{array}{l}\text { Thanks } \\
\text { outlining traditional and upcoming business }\end{array}$ \\
\hline
\end{tabular}


models for FM which also link to value chains

2. Relationship to Literature: The literature is well done and aid in the explanation as to why the work is important. There does seem a reliance on Jensen's work which is relevant, but would be interesting to get contrasting views.

3. Methodology: The paper does not include a clear method on how the author chose his literature which is important in a literature based paper. Including a clear method would aid in understanding the reliance on Jensen as opposed to other authors in the same field. Also, the author states at the end that case studies were part of the results. The author should therefore include a background and number of case studies included. Within the text - the author refers to case studies in other publications - but perhaps it is useful to produce a table of the different case studies discussed.

4. Results: Good and clear results with tables and underlying description of each business model and the context they work within.

5. Implications for research, practice and/or society: This is a useful source for eduation of FM and practitioners who want to know more about the different types of business models for FM.

6. Quality of Communication: The paper structure is done very well. The English needs a proof check. It is quite readable but some part are grammatically incorrect. Suggest moving the column of 'FM value chain' to be the first column in table 4.
With the revision and shortening of the paper, 9 references has been removed, including 5 from my own previous research, while 4 new references have been added.

See response to the first comment from reviewer 1 concerning literature.

Case studies are not part of the results but used to show examples and underpin the different sourcing strategies and business models.

\section{Thanks}

Thanks

(1)

The

\begin{tabular}{|l|l|}
\hline Reviewer 2 & Response \\
\hline $\begin{array}{l}\text { Overall the paper is good and comply with all } \\
\text { the requirements for publication. }\end{array}$ & $\begin{array}{l}\text { Thanks for the suggestion. However, due to } \\
\text { the requirement from the editor to reduce the } \\
\text { Size of the paper, I have not found it possible } \\
\text { It would interesting to see the results on a } \\
\text { table summary in one page, Just to have a } \\
\text { quick overview and understanding about the } \\
\text { relationship and logic of the work done and }\end{array}$ \\
\hline
\end{tabular}


the results. That would make the paper much easier to read and more engaging.

1. Originality: The paper contains significant information in the way that it connects the sourcing strategies, business models and value chains and the typical combinations in the FM industry.

The documents serves as a one sources of information to understand about business models in FM over the last years and also how they extend.

2. Relationship to Literature: Yes the paper contain a wide understanding of the literature and the years of experience of the author investigating about value and business models in the FM industry.

3. Methodology: The paper is conceptual, based on case studies and theories. The author provides the necessary content according to the methodology followed.

4. Results: Yes the results are presented correctly and analyzed properly. There is a good structural logic in the paper. 5. Implications for research, practice and/or society: The paper mentions that new disruptive business models can happen with more extended use of new technologies. I would like to see some examples of how this could happen or impact the industry. Especially from practice point of view what business models are already being disrupted. In practice this paper gives a general comprehensive reference for business models. I think future work from other researchers can study the vulnerability of how some business models can be changed or impacted.

6. Quality of Communication: The paper reads well, there are no communication issues.

Thanks

Thanks

Thanks

Thanks

Due to the requirement from the editor to reduce the size of the paper, I have skipped the paragraph mentioning disruption in the discussion. 